\title{
The adhesion and migration of microglia to $\beta$-amyloid $(A \beta)$ is decreased with aging and inhibited by Nogo/NgR pathway
}

Yinquan Fang ${ }^{1,2}$, Jianing Wang ${ }^{1}$, Lemeng Yao ${ }^{1}$, Chenhui Li ${ }^{1}$, Jing Wang ${ }^{1}$, Yuan Liu' ${ }^{1}$ Xia Tao ${ }^{1}$, Hao Sun ${ }^{1}$ and Hong Liao ${ }^{1 *}$ (D)

\begin{abstract}
Background: Alzheimer's disease is characterized by progressive accumulation of $\beta$-amyloid (A $\beta$ )-containing amyloid plaques, and microglia play a critical role in internalization and degradation of $A \beta$. Our previous research confirmed that Nogo-66 binding to Nogo receptors ( $\mathrm{NgR}$ ) expressed on microglia inhibits cell adhesion and migration in vitro.

Methods: The adhesion and migration of microglia isolated from WT and APP/PS1 mice from different ages were measured by adhesion assays and transwells. After NEP1-40 (a competitive antagonist of Nogo/NgR pathway) was intracerebroventricularly administered via mini-osmotic pumps for 2 months in APP/PS1 transgenic mice, microglial recruitment toward $A \beta$ deposits and CD36 expression were determined.

Results: In this paper, we found that aging led to a reduction of microglia adhesion and migration to $f A \beta_{1-42}$ in WT and APP/PS1 mice. The adhesion and migration of microglia to $f A \beta_{1-42}$ were downregulated by the Nogo, which was mediated by NgR, and the increased inhibitory effects of the Nogo could be observed in aged mice. Moreover, Rho GTPases contributed to the effects of the Nogo on adhesion and migration of microglia to $f A \beta_{1-42}$ by regulating cytoskeleton arrangement. Furthermore, blocking the Nogo/NgR pathway enhanced recruitment of microglia toward A $\beta$ deposits and expression of CD36 in APP/PS1 mice.

Conclusion: Taken together, Nogo/NgR pathway could take part in A $\beta$ pathology in AD by modulating microglial adhesion and migration to $A \beta$ and the Nogo/NgR pathway might be an important target for treating AD.
\end{abstract}

Keywords: Nogo, Nogo receptor, Microglia, A $\beta$, Adhesion, Migration, Alzheimer's disease

\section{Background}

Alzheimer's disease (AD) is the most frequent neurodegenerative disorder and the leading cause of dementia worldwide [1], progressing from minor memory problems to complete loss of cognitive functions and eventually death. Recently, many studies have found that neuroinflammation is one of the causes of $\mathrm{AD}$ [2]. Microglia, the primary immune cells of the brain, play a central role in the pathogenesis of $\mathrm{AD}$.

Microglia have a biphasic neurotoxic-neuroprotective role in the pathogenesis of $\mathrm{AD}[3]$. For instance, over-

\footnotetext{
* Correspondence: hliao@cpu.edu.cn

${ }^{1}$ Jiangsu Key laboratory of Drug Screening, China Pharmaceutical University, 24 Tongjiaxiang Street, Nanjing 210009, China

Full list of author information is available at the end of the article
}

activated microglia can release proinflammatory cytokines and neurotoxic molecules, which can exacerbate disease [4-6]. Conversely, microglia also migrate to, adhere to, and phagocytose $A \beta$, which could help clear $A \beta$ plaques from the brain parenchyma [7-9]. Interestingly, microglia revealed an age-dependent decrease in ability to phagocytose $A \beta$ fibrils and expression of $A \beta$-interacting protein is decreased in vitro [10]. Moreover, in line with progression of $\mathrm{AD}$ pathology, proinflammatory cytokines reduce expressions of $A \beta$-binding receptors and $A \beta$-degrading enzymes and further decrease ability of microglial $A \beta$ clearance [11].

As a member of the reticulon family, Nogo-A inhibits axonal extension and fibroblast spreading in CNS disease $[12,13]$. The Nogo receptor $(\mathrm{NgR})$ is a neuronal surface 
glycosyl phosphatidylinositol (GPI)-linked receptor, which binds to Nogo-66 (a hydrophilic 66 amino acids long region of Nogo-A) with high affinity $[14,15]$. Some studies reveal that Nogo and NgR are involved in the pathogenesis of AD. For example, expressions of Nogo-A and NgR are increased in patients with $\mathrm{AD}$ and in aged rats with deficits of spatial cognition [16-18]. Furthermore, Nogo and $\mathrm{NgR}$ are associated with $\mathrm{A} \beta[16,19]$, and it has been demonstrated that deleting Nogo ameliorates learning and memory deficits in APP transgenic mice [20], and subcutaneous $\mathrm{NgR}(310)$ ecto-Fc treatment reduces brain $\mathrm{A} \beta$ plaque load and improves spatial memory in APPswe/PSEN-1 $\triangle$ E9 transgenic mice [21].

Our previous research has confirmed that $\mathrm{NgR}$ is expressed on microglia and that Nogo-66 bindings with NgR could inhibit adhesion and migration of microglia through the RhoA/Rho associate kinase (ROCK) pathway in vitro [22]. The interaction of Nogo-P4 with NgR elevates the expressions of proinflammatory enzymes (iNOS and COX-2) and cytokines (IL-1 $\beta$, TNF- $\alpha$, NO, and PGE2) in primary microglia [23], and neuroinflammation mediated by the Nogo/NgR pathway in microglia plays a role in the formation of $\mathrm{A} \beta$ plaques in vitro and in vivo [24]. Moreover, with aging, the increased expression of $\mathrm{NgR}$ in microglia has been reported [25]. These findings provide a new insight into whether the Nogo participate in the adhesion and migration of microglia to $A \beta$. In this study, we found that as aging microglia exhibited decrease in adhesion and migration to $\mathrm{fA} \beta_{1-42}$ in vitro. The interaction of Nogo with NgR inhibited the adhesion and migration of microglia to $A \beta$, in which adhesion and migration are important processes of phagocytosis. Furthermore, cytoskeleton reorganization mediated by Rho GTPases also contributed to the effects of the Nogo on the adhesion and migration of microglia to $\mathrm{A} \beta$. Moreover, the blocking of the Nogo/NgR pathway enhanced microglial recruitment toward $A \beta$ deposits and expression of CD36 in APP/PS1 mice.

\section{Methods}

\section{Animals}

C57BL/6J mice were obtained from Vitalriver (Beijing, China). APP/PS1 transgenic mice were purchased from the animal model center of Nanjing University (Nanjing, China), and the mice were generated from the $\mathrm{B} 6 \mathrm{C} 3-\mathrm{Tg}$ (APPswe, PSEN1dE9) 85Dbo/J double transgenic mouse line (stock no. 004462) provided by the National Jackson Animal Center (Bar Harbor, Maine, USA). All of the mice were raised in a thermostatic 12-h/12-h dark-light cycle environment, with free access to food and water. All animal tests were carried out in accordance with the US National Institute of Health (NIH) Guide for the Care and Use of Laboratory. All experimental procedures were approved by the Institutional Animal Care and Use
Committee (IACUC) of the Nanjing Medical University Experimental Animal Department.

\section{Microglia from neonatal mice}

Primary microglia culture were prepared from cerebral cortex of neonatal C57BL/6J mice as described previously [23]. Briefly, meninges were removed from the brains and the cortex was enzymatically dissociated (0.25\% trypsinEDTA, Sigma, St Louis, MO, USA). Then, cells were suspended in Dulbecco's Modified Eagle's Medium/nutrient mixture F-12 (DMEM/F12, Gibco, Carlsbad, CA, USA) supplement with 10\% FBS (Gibco) and seeded into poly-L-lysine (PLL, $0.01 \mathrm{mg} / \mathrm{ml}$, Sigma) pre-coated T75 tissue culture flasks. After 3, 7, and 10 days, the culture medium was renewed. After 2 weeks in culture, the cells were isolated by gently shaking of the flask. About $95 \%$ of these cells were positive for CD11b, a marker for microglia cell types.

\section{Microglia from adult mice}

Three-month-old and 15-month-old C57BL/6J mice and 3-month-old and 15-month-old APP/PS1 mice were anesthetized with chloral hydrate $(100 \mathrm{mg} / \mathrm{kg}$, i.p.), and perfused with ice-cold D-Hanks' balanced salt solution to wash away all contaminating blood cells from the brain. The cerebellum and meninges were removed from the brains. Then, the tissue was dissected and dissociated in an enzymatic solution at $37{ }^{\circ} \mathrm{C}$ and $5 \% \mathrm{CO}_{2}$ and continuously stirred for $90 \mathrm{~min}$. The enzymatic solution [26] contained $116 \mathrm{mM} \mathrm{NaCl}, 5.4 \mathrm{mM} \mathrm{KCl}, 26 \mathrm{mM}$ $\mathrm{NaHCO}_{3}, 1 \mathrm{mM} \mathrm{NaH} 2 \mathrm{PO}_{4}, 1.5 \mathrm{mM} \mathrm{CaCl} 2,1 \mathrm{mM}$ $\mathrm{MgSO}_{4}, 0.5 \mathrm{mM}$ EDTA, $25 \mathrm{mM}$ glucose, $1 \mathrm{mM}$ cysteine, and 20 units/ml papain (Sigma). Next, the enzymatic reaction was quenched by the addition of $20 \mathrm{ml}$ of $20 \%$ FBS in D-Hank's. After centrifugation at $200 \mathrm{~g}$ for $7 \mathrm{~min}$ at room temperature, the tissues were dissociated in $0.05 \mathrm{mg} / \mathrm{ml}$ DNase I (Sigma) in D-Hank's and incubated for $5 \mathrm{~min}$ at room temperature. Then, the tissues were gently disrupted and filtered through a 70- $\mu \mathrm{m}$ cell strainer (Corning, New York, USA). To remove myelin [27], the cells were suspended in $20 \mathrm{ml} 20 \%$ stock isotonic Percoll $(\mathrm{SIP}=v / v$ ratio: 9/10 Percoll (GE Healthcare, Princeton, NJ, USA) + 1/10 D-Hank's 10×) in D-Hank's and centrifuged for $20 \mathrm{~min}$ at $500 \mathrm{~g}$ with slow acceleration and no brake. The supernatant containing the myelin was removed, and the pelleted cells were washed with D-Hank's. Then, the cells were incubated with anti-mouse CD11b-coated microbeads (Miltenyi Biotec, Bergisch Gladbach, Germany) for $15 \mathrm{~min}$ at $4{ }^{\circ} \mathrm{C}$. The cells were washed with washing buffer $(0.5 \%$ BSA, 2 mM EDTA in $\mathrm{PBS})$ to remove unbound beads. The cells were resuspended in washing buffer and passed over a magnetic MACS Cell Separation column (Miltenyi Biotec), and the column was rinsed twice with washing buffer. 
CD11b-positive microglia were eluted by removing the column from the magnetic holder and the pushing washing buffer through the column with a plunger. The cells were centrifuged and washed with DMEM/F12 containing 10\% FBS. Approximately $95 \%$ of these cells were positive for CD11b, a marker for microglia cell types.

\section{Western blot analysis}

After 2 months of administration, mice were deeply anesthetized with chloral hydrate $(100 \mathrm{mg} / \mathrm{kg}$, i.p.). After perfusion with $\mathrm{PBS}$, the brain was quickly dissected and stored at $-80{ }^{\circ} \mathrm{C}$ until further use. Snap-frozen brain tissue was homogenized in RIPA buffer (Beyotime Biotechnology Co., Shanghai, China) supplemented with a protease inhibitor cocktail (Roche Molecular Biochemicals, Indianapolis, IN, USA). Extracts were centrifuged at $12,000 \mathrm{~g}$ for $20 \mathrm{~min}$ at $4{ }^{\circ} \mathrm{C}$, and the supernatant was collected and the protein concentration was determined using bicinchoninic acid protein assay kit (Beyotime Biotechnology).

After different treatments, the cells were lysed in lysis buffer (Beyotime Biotechnology, Nanjing, China) containing a protease inhibitor cocktail (Roche Molecular Biochemicals). Debris were removed by centrifugation, and the supernatant was collected. The protein concentration was determined using bicinchoninic acid protein assay kit (Beyotime Biotechnology).

Equal amounts of protein $(30 \mu \mathrm{g})$ were separated electrophoretically using denaturing gels and transferred to nitrocellulose membranes. Subsequently, the membranes were blocked for $1 \mathrm{~h}$ at room temperature with 5\% BSA in TBST and incubated with following primary antibody overnight at $4{ }^{\circ} \mathrm{C}$ : rabbit anti-p-Myosin Light Chain 2 (MLC) at Ser19 polyclonal antibody (1:1000; 3671; Cell Signaling Technology Inc., Danvers, MA, USA), rabbit anti-MLC polyclonal antibody (1:1000; 3672; Cell Signaling Technology Inc.), rabbit anti-p-cofilin at Ser3 polyclonal antibody (1:1000; 3311; Cell Signaling Technology Inc.), rabbit anti-cofilin polyclonal antibody $(1: 1000$; 3318; Cell Signaling Technology Inc.), mouse anti- $\beta$-actin monoclonal antibody (1:2000; sc-47778; Santa Cruz Biotechnology, MA, USA), rabbit anti-CD36 polyclonal antibody (1:1000; NB400-144; Novus Biologicals, Littleton, CO, USA), rabbit anti-Ras GTPase-activating-like protein (IQGAP) polyclonal antibody (1:1000; ab133490; Abcam, Cambridge, MA, USA). After washed with TBST thrice, the membranes were incubated with horseradish peroxidase-conjugated secondary antibodies anti-mouse IgG (1:10000; RABHRP2; Sigma) or anti-rabbit IgG (1:5000; 7074; Cell Signaling Technology Inc.). The immunoreactive bands were visualized using chemiluminescence reagents (ECL; Millipore, Billerica, MA, USA) and captured with Bio-Rad Gel Doc
XR documentation system. Pixel density of bands was performed using Quantity One software.

\section{Preparation of fibrillar $A \beta$ ( $f A \beta$ )}

$A \beta_{1-42}$ or $A \beta_{42-1}$ (all from AnaSpec Inc., San Jose, California, USA) lyophilized powder was dissolved to $1 \mathrm{mg} / 200 \mu \mathrm{l}$ in 100\% hexafluoroisopropanol and aliquoted into $10 \mu \mathrm{l}$ portions, dried in a vacuum centrifuge, and stored at $-20^{\circ} \mathrm{C}$. To fibrillize, $A \beta_{1-42}$ and $A \beta_{42-1}$ peptides were resuspended in sterile $\mathrm{dd}_{2} \mathrm{O}$ followed by incubation for 1 week at $37{ }^{\circ} \mathrm{C}[28,29]$. The Congo Red dye binding assay [30] was used to valid the fA $\beta$.

\section{Adhesion assay}

Adhesion assay was performed according to previous described method [22]. The methanol-solubilized nitrocellulose was added into 24-wells for 1 s, washed using $\mathrm{ddH}_{2} \mathrm{O}$, and air-dried under a sterile hood. Two microliter spots of BSA $(0.01 \%$ in PBS), Rtn-P4 $(100 \mu \mathrm{g} / \mathrm{ml})$, Nogo-P4 $(100 \mu \mathrm{g} / \mathrm{ml}), \mathrm{fA} \beta_{1-42}(10 \mu \mathrm{M})$, Rtn-P4 $(100 \mu \mathrm{g} / \mathrm{ml})+$ $\mathrm{fA} \beta_{1-42}(10 \mu \mathrm{M})$, Nogo-P4 $(100 \mu \mathrm{g} / \mathrm{ml})+\mathrm{fA} \beta_{1-42}(10 \mu \mathrm{M})$, or $f A \beta_{42-1}(10 \mu \mathrm{M})$ were applied in duplicate to the nitrocellulose-coated surfaces of the wells and incubated overnight at $4{ }^{\circ} \mathrm{C}$. In the absence or presence of phosphatidylinositol-specific phospholipase C (PI-PLC, $0.3 \mathrm{U} / \mathrm{ml}$, Sigma), NEP1-40 (10 $\mu \mathrm{M}$, Millipore) or Y27632 [(1)-(R)-trans-4-(1-aminoethyl)-N-(4-pyridyl) cyclohexanecarboxamide dihydrochloride] $(50 \mu \mathrm{M}$, CalbiochemNovabiochem., San Diego, CA, USA) for $30 \mathrm{~min}$, freshly isolated microglia were seeded in the pre-coated wells for adhesion assay. After $24 \mathrm{~h}$, the plate was washed thrice with PBS, and the cells were fixed with $4 \%$ paraformaldehyde and stained with Crystal Violet solution (0.2\%). The number of cells adhering to fields which pre-coated by protein spots referred above was randomly counted under microscopy.

\section{Migration assay}

Costar Transwells (polycarbonate filter, $8 \mathrm{~lm}$-pore size, Millipore) were used in the migration assay to examine the ability of microglial migration [22]. The undersurfaces of transwell membranes were coated with BSA $(0.01 \%$ in PBS), Rtn-P4 (100 $\mu \mathrm{g} / \mathrm{ml})$, Nogo-P4 $(100 \mu \mathrm{g} / \mathrm{ml}), \mathrm{fA} \beta_{1-42}$ $(10 \mu \mathrm{M})$, Rtn-P4 $(100 \mu \mathrm{g} / \mathrm{ml})+\mathrm{fA} \beta_{1-42}(10 \mu \mathrm{M})$, Nogo-P4 $(100 \mu \mathrm{g} / \mathrm{ml})+\mathrm{fA} \beta_{1-42}(10 \mu \mathrm{M})$, or fA $\beta_{42-1}(10 \mu \mathrm{M})$ overnight at $4{ }^{\circ} \mathrm{C}$. Freshly isolated microglia untreated or treated with PI-PLC $(0.3 \mathrm{U} / \mathrm{ml})$, NEP1-40 (10 $\mu \mathrm{M})$, or $\mathrm{Y} 27632(50 \mu \mathrm{M})$ for $30 \mathrm{~min}$ were suspended in serum-free culture medium and planted into the upper chamber for migration assay. After $24 \mathrm{~h}$, the inserts were fixed with $4 \%$ paraformaldehyde and stained with Crystal Violet solution (0.2\%). After washing with PBS, cells from the inner surface of the insert were gently wiped out with cotton-tipped swabs, and the cells from 
the outer surface of the insert were counted under microscope at five fields per filter.

\section{RhoA, Rac1, and Cdc42 activity assay}

To measure the activity of RhoA, Rac1, and Cdc42, 96-well plates were coated with methanol-solubilized nitrocellulose and air-dried under a sterile hood. PLL coating on the nitrocellulose-coated surfaces of the wells was performed to promote microglia adhesion. Then, BSA (0.01\% in PBS), fA $\beta_{1-42}(10 \mu \mathrm{M})$, Nogo-P4 $(100 \mu \mathrm{g} / \mathrm{ml})$, or Nogo-P4 $(100 \mu \mathrm{g} / \mathrm{ml})+\mathrm{fA} \beta_{1-42}(10 \mu \mathrm{M})$ were coated on the wells overnight at $4{ }^{\circ} \mathrm{C}$. Adult microglia were added into the pre-coated wells and cultured for $6 \mathrm{~h}$.

The activity of RhoA, Rac1, and Cdc42 were determined by commercial Rho Activation Assay Kit (Millipore) and Rac1/Cdc42 Activation Assay Kit (Millipore) following the manufacturer's instructions.

\section{F-actin staining}

For observing F-actin, microglia were cultured in 96-well plates pre-coated with $\mathrm{BSA}(0.01 \%$ in $\mathrm{PBS}), \mathrm{fA} \beta_{1-42}$ $(10 \mu \mathrm{M})$, Nogo-P4 $(100 \mu \mathrm{g} / \mathrm{ml})$, or Nogo-P4 $(100 \mu \mathrm{g} / \mathrm{ml})+$ $\mathrm{fA} \beta_{1-42}(10 \mu \mathrm{M})$ in the absence or presence of PI-PLC $(0.3 \mathrm{U} / \mathrm{ml}), \mathrm{NEP} 1-40(10 \mu \mathrm{M})$, or Y27632 $(50 \mu \mathrm{M})$ for $8 \mathrm{~h}$. Then, the cells were fixed with $4 \%$ paraformaldehyde and permeabilized with $0.1 \%$ Triton X-100 in PBS. After incubating with $0.5 \mu \mathrm{g} / \mathrm{ml}$ TRITC-phalloidin (Sigma) for $30 \mathrm{~min}$ at room temperature, fluorescence was then examined by fluorescence microscopy. For quantification of cell spread, the spread areas were calculated and analyzed using the Image-Pro Plus software. The average spread areas of the cells in each group were expressed as the percentage of spread areas of the BSA group.

\section{NEP1-40 treatment}

To deliver NEP1-40 peptide, 6-month-old male APP/PS1 mice were anesthetized with chloral hydrate $(100 \mathrm{mg} / \mathrm{kg}$, i.p.), and a burr hole was drilled on the skull. A cannula (Alzet brain infusion kit II; Alza, Palo Alto, CA) was stereotactically introduced into the right lateral ventricle at the coordinates: $0.6 \mathrm{~mm}$ posterior and $1.2 \mathrm{~mm}$ lateral to bregma and $2.0 \mathrm{~mm}$ deep to the pial surface. The cannula was held in place with cyanoacrylate, and the catheter was attached to osmotic micropump (Alzet 2004, $0.25 \mu \mathrm{l} / \mathrm{h}$ for $28 \mathrm{~d}$; Alza). The pump was placed subcutaneously in the mid scapular area of the back of the mice. Animals were categorized into vehicle $(97.5 \% \mathrm{PBS}+2.5 \%$ DMSO, 10 male APP/PS1 mice, 5 mice for Western blot, and 5 mice for immunofluorescence)-treated and NEP1-40 (500 $\mu \mathrm{M}$ in vehicle, 8 male APP/PS1 mice, 4 mice for Western blot, and 4 mice for immunofluorescence)-treated groups. Pumps were replaced after 28 days and connected to the same cannula.

\section{Tissue preparation}

After infusion for 2 months, mice were deeply anesthetized using chloral hydrate $(100 \mathrm{mg} / \mathrm{kg}$, i.p.) and perfused intracardially with cold $4 \%$ paraformaldehyde (PFA) in PBS followed by perfusion with PBS. Brain tissues were fixed with PFA overnight at $4{ }^{\circ} \mathrm{C}$ and equilibrated by immersing in 15 and $30 \%$ sucrose in PBS overnight at $4{ }^{\circ} \mathrm{C}$, respectively. Brain tissues were then sectioned to a thickness of $15 \mu \mathrm{m}$ on Leica-1900 cryostat (Leica Instruments, Germany). Sections were used for immunofluorescence and stored at $-80^{\circ} \mathrm{C}$.

\section{Immunofluorescence}

Immunofluorescence was performed as described earlier with some modifications [31]. Briefly, brain sections were degreased in acetone for $20 \mathrm{~min}$ at $4{ }^{\circ} \mathrm{C}$. After incubated with a blocking solution (10\% normal goat serum, $0.3 \%$ Triton X-100 in PBS) at room temperature for $1 \mathrm{~h}$, the sections were incubated with primary antibodies overnight at $4{ }^{\circ} \mathrm{C}$. The following primary antibodies were used: mouse anti-6E10 monoclonal antibody (1:500; SIG-39300; Covance, Princeton, NJ), mouse anti-12F4 monoclonal antibody (1:500; SIG-39144; Covance), and rabbit antiIba-1 polyclonal antibody (1:200; 019-19741; Wako Chemicals, Japan). After rinsing in PBS, sections were incubated with secondary antibodies: Alexa Fluor-488conjugated goat anti-rabbit IgG antibody (1:300; R11034; Invitrogen, Carlsbad, CA) and Alexa Fluor594-conjugated goat anti-mouse IgG antibody (1:500; R11005; Invitrogen). The fluorescent imaging was visualized by using Olympus IX-81-inverted fluorescence microscope and FV1000 confocal laser scanning microscope (Olympus Corporation, Japan).

\section{Statistical analysis}

All present data represent the results of three independent experiments and repeats twice within each experiment. Statistical analysis was performed using one-way analysis of variance (ANOVA) with post hoc Tukey's tests or Student's $t$ tests using GraphPad Prism 6 software (GraphPad Software Inc., La Jolla, CA, USA). Two-way ANOVAs followed by post hoc Tukey's tests were utilized for multiple-factor comparisons of the parameters in Figs. 1 and 2 . All data were presented as mean \pm SD. $p$ values of $" p<0.05$ was considered statistically significant.

\section{Results}

Aging led to decreased adhesion and migration of microglia to $A \beta$ fibrils

In $\mathrm{AD}$, microglia migrates and adheres to $\mathrm{A} \beta$ plaque deposition [32-34], and the processes have been shown to participate in the clearance of $A \beta$ plaques via phagocytosis and degradation of $A \beta[35,36]$. The aggregation of $f A \beta_{1-42}$ was validated by the Congo Red dye binding 


\section{Adhesion}

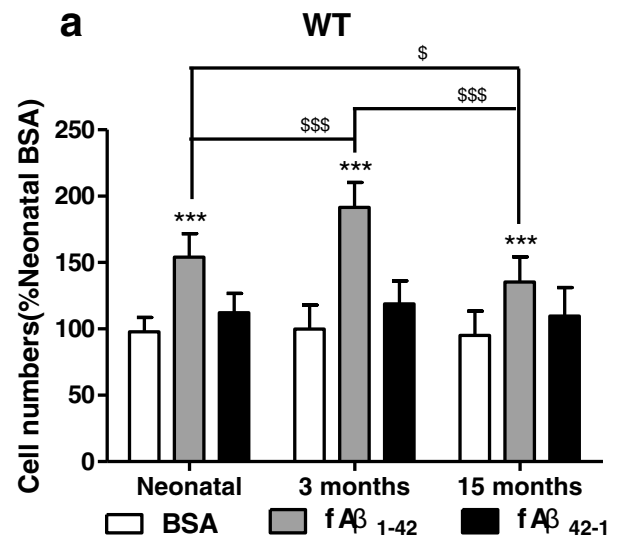

b

APP/PS1
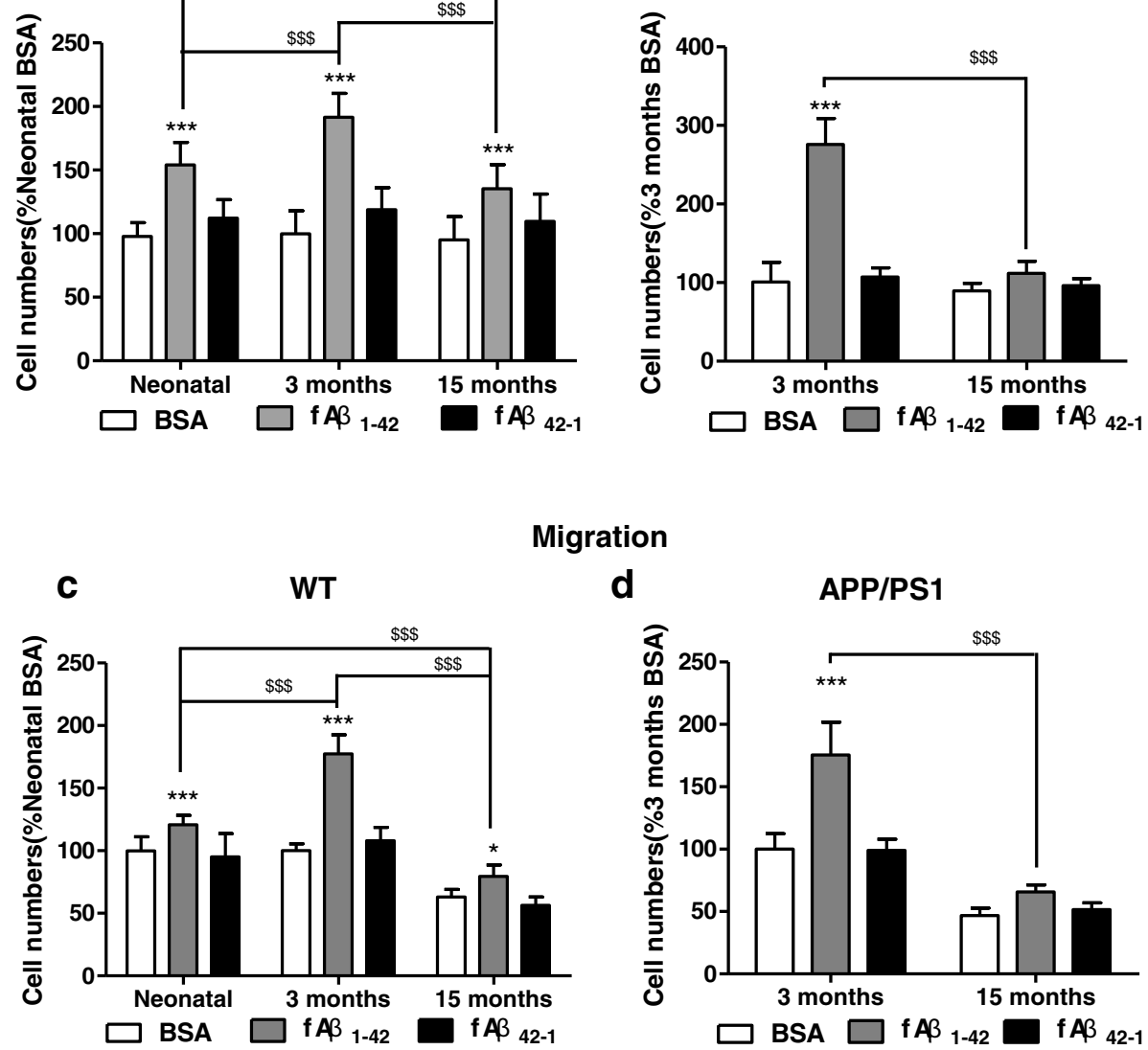

Migration

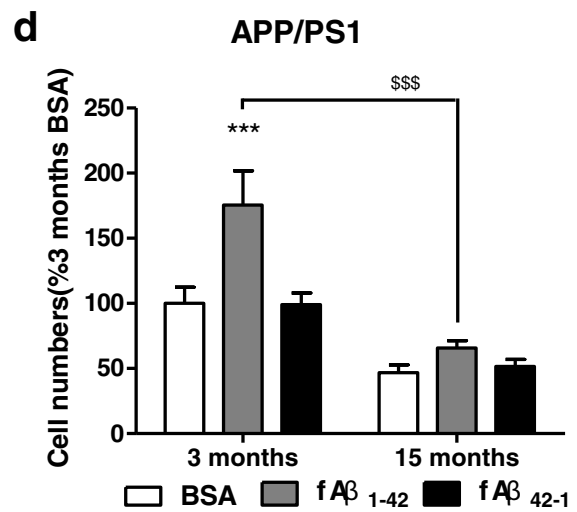

Fig. 1 Aging led to decreased adhesion and migration of microglia to A $\beta$ fibrils. Microglia from mice of various ages were isolated, and the effects of adhesion and migration of microglia to $f A \beta$ were determined using adhesion and migration assays. $\mathbf{a}, \mathbf{b}$ The adhesion of microglia to fAß. Microglia isolated from neonatal, 3-month-old, 15-month-old WT mice or 3-month-old, and 15-month-old APP/PS1 mice were plated on spots of $B S A\left(0.01 \%\right.$ in PBS), $f A \beta_{1-42}(10 \mu M)$ or $f A \beta_{42-1}(10 \mu M)$ for $24 \mathrm{~h}$. The numbers of cells within spot areas were quantified. a WT mice. $\mathbf{b}$ APP/PS1 mice. c, $\mathbf{d}$ The migration of microglia to $f A \beta$. Microglia isolated from neonatal, 3-month-old, 15-month-old WT mice or 3-month-old, and 15 -month-old APP/PS1 mice were added to transwell membranes coated on their underside with BSA (0.01\% in PBS), fA $\beta_{1-42}(10 \mu M)$, or fA $\beta_{42-1}$ $(10 \mu \mathrm{M})$ for $24 \mathrm{~h}$. The numbers of cells that transmigrated through the transwell membranes were quantified. $\mathbf{c}$ WT mice. d APP/PS1 mice. Values were reported as the mean $\pm \mathrm{SD}$, as a percentage of values determined in BSA group of neonatal mice (control, $100 \%$ ). ${ }^{*} p<0.05,{ }^{* *} p<0.01$, ${ }^{* * *} p<0.001$, when compared with the BSA group; ${ }^{\$} p<0.05,{ }^{\$ \$ \$} p<0.001, n=3$

assay (Additional file 1: Figure S1). To investigate effects of aging on adhesion and migration of microglia to $A \beta$ fibrils, microglia from WT and APP/PS1 mice of various ages were isolated, and adhesion and migration of microglia to $f A \beta$ were determined. $f A \beta$ did not influence proliferation of microglia (Addtional file 2: Figure S2). Quantification of the data (Fig. 1a, b) showed that, compared with BSA spots, the numbers of microglia isolated from WT and APP/PS1 mice adhering to $\mathrm{fA} \beta_{1-42}$ were increased. There was no significant change in the numbers of microglia isolated from WT and APP/PS1 mice adhering to $\mathrm{fA} \beta_{42-1}$ (rev $A \beta$ ) spots (Fig. 1a, b). $A \beta_{42-1}$ is the reverse peptide of $A \beta_{1-42}$ and does not exert the activity of $A \beta_{1-42}$. Corresponding with the results of the adhesion assay, the numbers of microglia isolated from WT and APP/PS1 mice that transmigrate to the underside of $\mathrm{fA} \beta_{1-42}$ were increased when compared with the BSA-treated transwell (Fig. 1c, d). There was no significant change in the numbers of microglia isolated from WT and APP/PS1 mice migrating to $\mathrm{AA} \beta_{42-1}$ (Fig. 1c, d). These data suggested that adhesion and migration of microglia were increased by $\mathrm{fA} \beta_{1-42}$.

Compared with neonatal WT mice, adhesion and migration of microglia to $f A \beta_{1-42}$ were significantly increased in 3-month-old WT mice (Fig. 1a, c). Furthermore, adhesion and migration of microglia to $\mathrm{fA} \beta_{1-42}$ were significantly decreased in 15-month-old WT mice (Fig. 1a, c). Consistent with the results in WT mice, adhesion and migration of microglia to $f A \beta_{1-42}$ were 


\section{Adhesion}

a

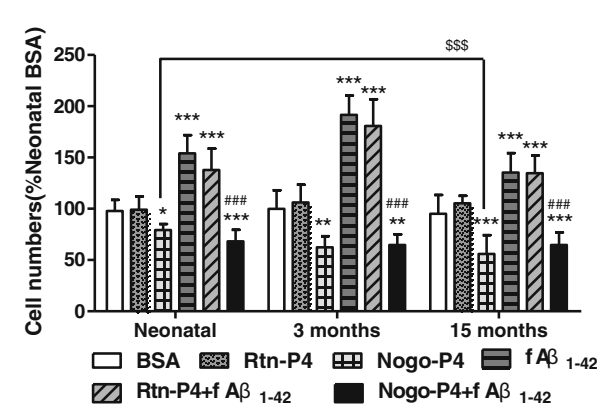

b

APP/PS1

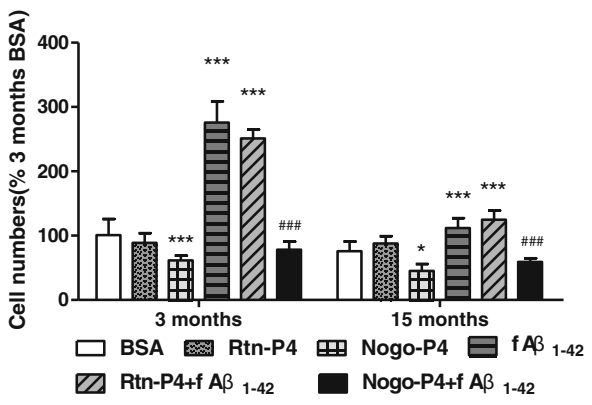

Migration

C

WT

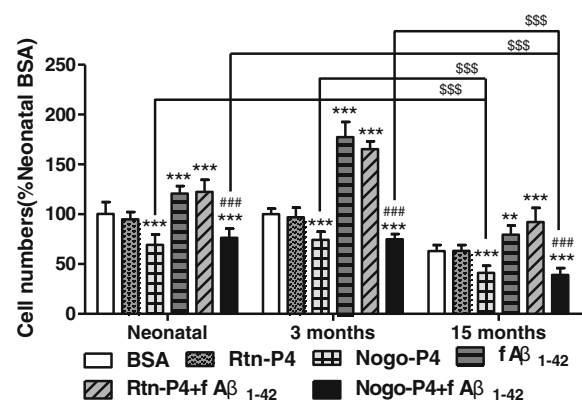

d

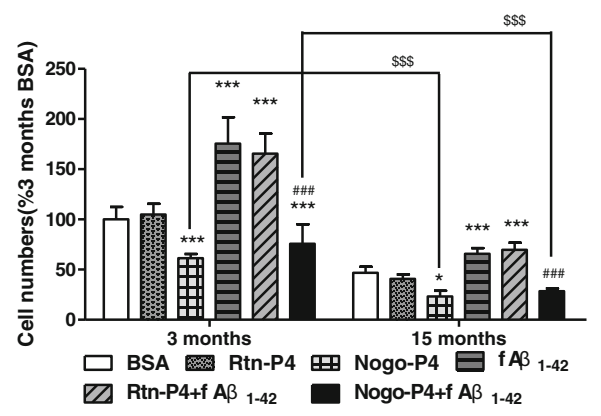

Fig. 2 Adhesion and migration of microglia induced by A $\beta$ fibrils were decreased by Nogo-P4. The effects of Nogo on the adhesion and migration of microglia isolated from WT and APP/PS1 mice in different ages to fA 3 were measured. $\mathbf{a}$, $\mathbf{b}$ Nogo-P4 inhibited adhesion of microglia to A $\beta$ fibrils. Microglia isolated from neonatal, 3-month-old, 15-month-old WT mice or 3-month-old, and 15-month-old APP/PS1 mice were plated on spots of BSA $\left(0.01 \%\right.$ in PBS), Rtn-P4 $(100 \mu \mathrm{g} / \mathrm{ml})$, Nogo-P4 $(100 \mu \mathrm{g} / \mathrm{ml})$, fA $\beta_{1-42}(10 \mu \mathrm{M})$, Rtn-P4 $(100 \mu \mathrm{g} / \mathrm{ml})+\mathrm{fA} \beta_{1-42}(10 \mu \mathrm{M})$, or Nogo-P4 $(100 \mu \mathrm{g} / \mathrm{ml})+\mathrm{fA} \beta_{1-42}(10 \mu \mathrm{M})$ for $24 \mathrm{~h}$. The numbers of cells within spot areas were quantified. a WT mice. b APP/PS1 mice. c, d Nogo-P4 inhibited the migration of microglia to A $\beta$ fibrils. Microglia isolated from neonatal, 3-month-old, 15-month-old WT mice or 3-month-old, and 15-month-old APP/PS1 mice were added to transwell membranes coated on their underside with BSA (0.01\% in PBS), Rtn-P4 (100 $\mu \mathrm{g} / \mathrm{ml})$, Nogo-P4 $(100 \mu \mathrm{g} / \mathrm{ml})$, fA $\beta_{1-42}(10 \mu \mathrm{M})$, Rtn-P4 $(100 \mu \mathrm{g} / \mathrm{ml})+f A \beta_{1-42}(10 \mu \mathrm{M})$, or Nogo-P4 $(100 \mu \mathrm{g} / \mathrm{ml})+f A \beta_{1-42}(10 \mu \mathrm{M})$ for $24 \mathrm{~h}$. The numbers of cells that transmigrated through the transwell membranes were quantified. $\mathbf{c}$ WT mice. $\mathbf{d}$ APP/PS1 mice. Values were reported as the mean \pm SD, as a percentage of values determined in BSA group of neonatal mice (control, $100 \%$ ). ${ }^{* *} p<0.01,{ }^{* * *} p<0.001$, when compared with the BSA

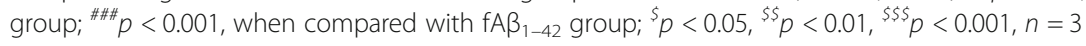

significantly decreased by aging in APP/PS1 mice (Fig. 2b, d). Taken together, these results implied that microglia derived from aged mice exhibited declines in the adhesion and migration to $\mathrm{fA} \beta_{1-42}$.

As showed in Fig. 1c, d, the migration of microglia in BSA or $\mathrm{fA} \beta_{42-1}$ significantly decreased in 15 -month-old WT and APP/PS1 mice. It could be concluded that the migration, not the adhesion, of microglia in BSA and $\mathrm{fA} \beta_{42-1}$ decreased with aging.

The adhesion and migration of microglia induced by $A \beta$ fibrils were decreased by the Nogo

It has been reported that Nogo-A is localized in the senile plaques of patients with $\mathrm{AD}$ [16], and the interaction of Nogo-66 and NgR inhibits adhesion and migration of microglia [22]. The effects of Nogo on the adhesion and migration of microglia isolated from WT and APP/PS1 mice in different ages to $f A \beta$ were measured. Nogo-66 is a 66-aa hydrophilic region of Nogo located between the two TM domains and has the inhibitory properties of Nogo-A. Nogo-P4 is a 25 aa inhibitory peptide sequence (residues 31-55 of Nogo-66), the active segment of Nogo-66, and has the core inhibitory activity of Nogo-66 [12]. These results in Fig. 2a, b showed that compared with BSA spots, the numbers of microglia isolated from WT and APP/PS1 mice adhering to Nogo-P4 were decreased and there was no significant change in the number of microglia adhering to Rtn-P4 spots, in which Rtn-P4 indicates as Reticulon 1 (Rtn1) non-inhibitory control/blocking peptide of NogoP4. Moreover, in contrast to the spots harboring BSA or $\mathrm{fA} \beta_{1-42}$ alone, microglia isolated from WT and APP/PS1 mice did not adhere well to the spots containing Nogo-P4 
and $\mathrm{fA} \beta_{1-42}$ and Rtn-P4 had no effect (Fig. 2a, b), suggesting that Nogo-P4 has an anti-adherent effect on microglia to $f A \beta_{1-42}$. Next, migration of microglia isolated from WT and APP/PS1 mice was characterized and results showed that number of microglia that transmigrated to the underside of Nogo-P4 was reduced when compared with BSA-treated transwells (Fig. 2c, d). There was no significant change in the numbers of microglia migrating to Rtn-P4 (Fig. 2c, d). Moreover, Nogo-P4 significantly inhibited the migration of microglia to $f A \beta_{1-42}$ compared with BSA or $\mathrm{fA} \beta_{1-42}$ groups and Rtn-P4 had no effect (Fig. 2c, d), indicating that Nogo-P4 could inhibit migration of microglia to $\mathrm{fA} \beta$. Furthermore, compared with neonatal WT mice, the inhibitory effects of Nogo on the adhesion of microglia were increased in 15-month-old WT mice (Fig. 2a), which was similar in APP/PS1 mice (Fig. 2b). Additionally, the inhibitory effect of Nogo on migration of microglia to $f A \beta_{1-42}$ was significantly increased with aging in WT mice and APP/PS1 mice (Fig. 2c, d). Taken together, these results suggested that Nogo decreased adhesion and migration of microglia to fA $\beta_{1-42}$ and the increased inhibitory effects could be observed in aging microglia isolated from WT and APP/PS1 mice.

Rather than early postnatal microglia, adult microglia may provide a more relevant model for identifying the precise microglia- $A \beta$ interaction during disease [37-40]. Adult microglia isolated from 3-month-old WT mice were chosen to study the further mechanism. Our previous research demonstrated that $\mathrm{NgR}$ is expressed on microglia [22] and that $\mathrm{NgR}$ protein expression is significantly increased in microglia with aging [25]. Next, we pretreated microglia with NEP1-40 $(10 \mu \mathrm{M})$ or PI-PLC $(0.3 \mathrm{U} / \mathrm{ml})$ and then observed the effects of NgR on the inhibitory effects on the adhesion and migration of microglia to fA $\beta_{1-42}$. NEP1-40 is a competitive antagonist peptide derived from the first 40 amino acids of the Nogo-66 and promotes axonal outgrowth through blocking the binding of Nogo-66 to NgR [41]. The enzymatic action of PI-PLC results in the release of GPI anchored NgR from the cell surface [14]. As shown (Fig. 3a, c), the effects of Nogo-P4 on adult microglial adherence and migration to $\mathrm{fA} \beta_{1-42}$ was significantly reversed by NEP1-40 or PI-PLC treatment. However, NEP1-40 or PI-PLC treatment alone had no effects in microglial adhesion and migration induced by $\mathrm{fA} \beta_{1-42}$ (Fig. $3 \mathrm{~b}, \mathrm{~d}$ ). These results suggest that the Nogo/NgR pathway took part in the effects of $f A \beta_{1-42}$ on the microglial adhesion and migration.

\section{Rho GTPases were involved in the inhibitory effects of Nogo on microglial adhesion and migration to $A \beta$ fibrils} Rho GTPases including Rho, Rac1, and Cdc42 are best known as regulators of the actin cytoskeleton, cell polarity, microtubule dynamics, and vesicular trafficking [42], which participate in the processes of cell adhesion and migration. Binding of Nogo-66 with NgR could activate RhoA and its downstream molecule ROCK, which contributes to adhesion and migration of microglia [22]. To determine whether RhoA acts as an intracellular signal transducer for effects of Nogo-P4 on microglial adherence and migration to $f A \beta_{1-42}$, RhoA activity was measured. The amount of activated RhoA of adult microglia in $\mathrm{fA} \beta_{1-42}$, Nogo-P4, or Nogo-P4 $+\mathrm{fA} \beta_{1-42}$-coated wells was higher than BSA substrate-coated well (Fig. 4a, b). To investigate the role of the RhoA/ROCK pathway on the effects of Nogo-P4 on adhesion and migration of microglia to $\mathrm{fA} \beta_{1-42}$, adult microglia were pre-treated with Y27632 $(50 \mu \mathrm{M})$ to block the function of ROCK before performing the adhesion or migration assay. Y27632 is widely used as a specific inhibitor of ROCK [43, 44]. The results (Fig. 4c-f) showed that treatment with Y27632 alone did not significantly affect the increased adhesion and migration of adult microglia induced by $\mathrm{fA} \beta_{1-42}$. Y27632 pre-treatment exhibited obvious conversion effects of Nogo-P4 on adult microglial adherence and migration to $\mathrm{fA} \beta_{1-42}$ (Fig. 4c-f). The data above implying that the RhoA/ROCK pathway is involved in the inhibited effects of Nogo-P4 on microglial adhesion and migration to $f A \beta_{1-42}$.

Cdc42 and Rac1 regulate the direction of migration, and RhoA promotes actin: myosin contractions in the cell body and at the rear [42]. The effects of $\mathrm{fA} \beta_{1-42}$ and Nogo-P4 on the activity of Cdc42 and Rac1 in adult microglia were measured. The results in Fig. $4 \mathrm{~g}-\mathrm{j}$ showed that $\mathrm{fA} \beta_{1-42}$ promoted the activation of $\mathrm{Cdc} 42$ and Rac1, while Nogo-P4 decreased the activation of Cdc42 and Rac1 in adult microglia. Moreover, Nogo-P4 inhibited the activity of Cdc42 and Rac1 induced by $\mathrm{fA} \beta_{1-42}$ in adult microglia (Fig. $4 \mathrm{~g}-\mathrm{j}$ ). These results indicated that activation of $\mathrm{Cdc} 42$ and Rac1 induced by fA $\beta_{1-42}$ were decreased by Nogo-P4, which may contribute to the effects of Nogo-P4 on adhesion and migration of microglia to fA $\beta$.

\section{Nogo/NgR pathway regulated microglia spreading and membrane protrusion formation induced by $A \beta$ fibrils} Cytoskeleton reorganization is closely related to cell adhesion and migration. Rho GTPases are the critical mediators in regulating the formation of distinct actin filament-containing structures, which is mediated by downstream molecules such as myosin-regulatory light chain (MLC) and cofilin [45]. Western blot results showed that $\mathrm{fA} \beta_{1-42}$, Nogo-P4 or Nogo-P4, and $\mathrm{fA} \beta_{1-42}$ significantly promoted phosphorylation levels of MLC (Fig. 5a, b) and cofilin (Fig. 5c, d). The scaffolding protein IQGAP, which can be activated by either Cdc42 or Rac, might be involved in cell migration [46]. Compared with BSA, expression of IQGAP was increased by $\mathrm{fA} \beta_{1-42}$ and 


\section{Adhesion}
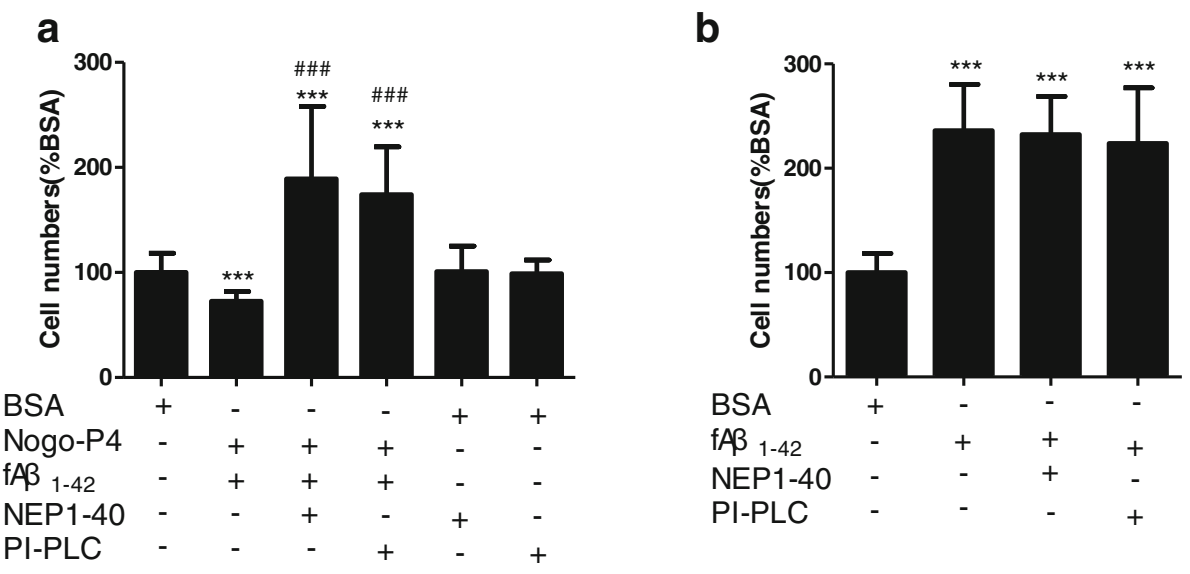

\section{Migration}

C

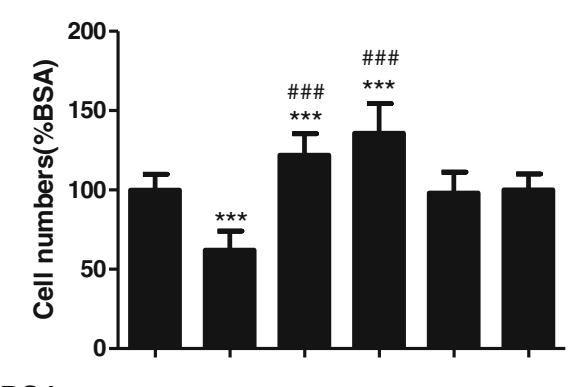

$\begin{array}{lllllll}\text { BSA } & + & - & - & - & + & + \\ \text { Nogo-P4 } & - & + & + & + & - & - \\ \text { fAB 1-42 } & - & + & + & + & - & - \\ \text { NEP1-40 } & - & - & + & - & + & - \\ \text { PI-PLC } & - & - & - & + & - & +\end{array}$ d

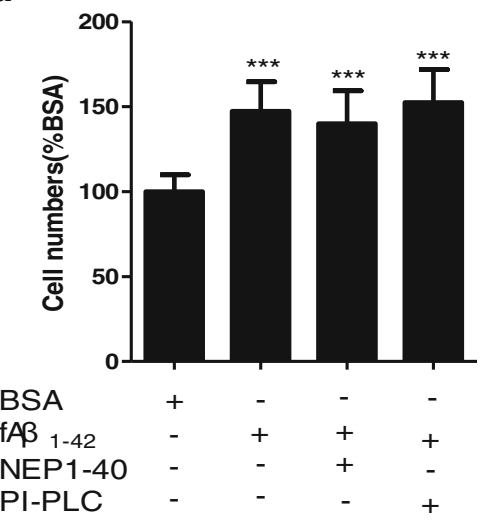

Fig. $3 \mathrm{NgR}$ mediated the effects of Nogo-P4 on adhesion and migration of adult microglia to $\mathrm{fA} \beta$. $\mathbf{a}, \mathbf{b} \mathrm{NgR}$ mediated the effect of Nogo-P4 on adhesion of adult microglia to $\mathrm{fA} \beta_{1-42}$. Before adding to wells pre-coated with BSA (0.01\% in PBS), fA $\beta_{1-42}(10 \mu \mathrm{M})$, or Nogo-P4 (100 $\left.\mu \mathrm{g} / \mathrm{ml}\right)+$ $\mathrm{fA} \beta_{1-42}(10 \mu \mathrm{M})$, microglia from 3-month-old mice were pretreated with NEP1-40 $(10 \mu \mathrm{M})$ or PI-PLC (0.3 U/ml) for $30 \mathrm{~min}$ to interrupt the function of $\mathrm{NgR}$. The numbers of cells within spot areas were quantified. $\mathbf{c}, \mathbf{d} \mathrm{NgR}$ mediated the effect of Nogo-P4 on migration of adult microglia to $f A \beta_{1-42}$. Before adding into the transwells pre-coated with BSA $\left(0.01 \%\right.$ in PBS), fA $\beta_{1-42}(10 \mu \mathrm{M})$, or Nogo-P4 (100 $\left.\mu \mathrm{g} / \mathrm{ml}\right)+\mathrm{fA} \beta_{1-42}(10 \mu \mathrm{M})$, microglia from 3-month-old mice were pretreated with NEP1-40 (10 $\mu \mathrm{M})$ or PI-PLC $(0.3 \mathrm{U} / \mathrm{ml})$ for 30 min to interrupt the function of NgR. The cell numbers transmigrated through transwell membranes were quantified. Values were reported as the mean \pm SD, as a percentage of values

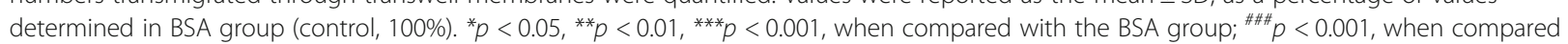
with the Nogo-P4 $+\mathrm{fA} \beta_{1-42}$ group, $n=3$

was decreased by Nogo-P4 in adult microglia (Fig. 5e, f). Moreover, Nogo-P4 inhibited expression of IQGAP induced by $\mathrm{fA} \beta_{1-42}$ in adult microglia (Fig. 5e, f).

To further explore the effect of Nogo-P4 on cytoskeleton reorganization of microglia and associated mechanism, F-actin staining and the mean spread area in the microglia were examined. Adult microglia stimulated by BSA showed multiple membrane protrusions and spread normally, and fA $\beta_{1-42}$ promoted more membrane protrusions and the spread of cells, while Nogo-P4 or Nogo-P4 +
$\mathrm{fA} \beta_{1-42}$ induced a rapid rounding up of adult microglia that had lost polarization and lacked processes and protrusions (Fig. 6a). The mean spread area from adult microglia was significantly reduced in Nogo-P4 compared with BSA treatment (Fig. 6b). Moreover, compared with $f A \beta_{1-42}$ treatment, mean spread area induced by $\mathrm{fA} \beta_{1-42}$ was decreased by Nogo-P4 (Fig. 6b), which was consistent with the insufficient adhesion and migration of microglia to fA $\beta_{1-42}$ after expose to Nogo-P4. Furthermore, NEP1-40 or PI-PLC pre-treatment could convert the effects of 


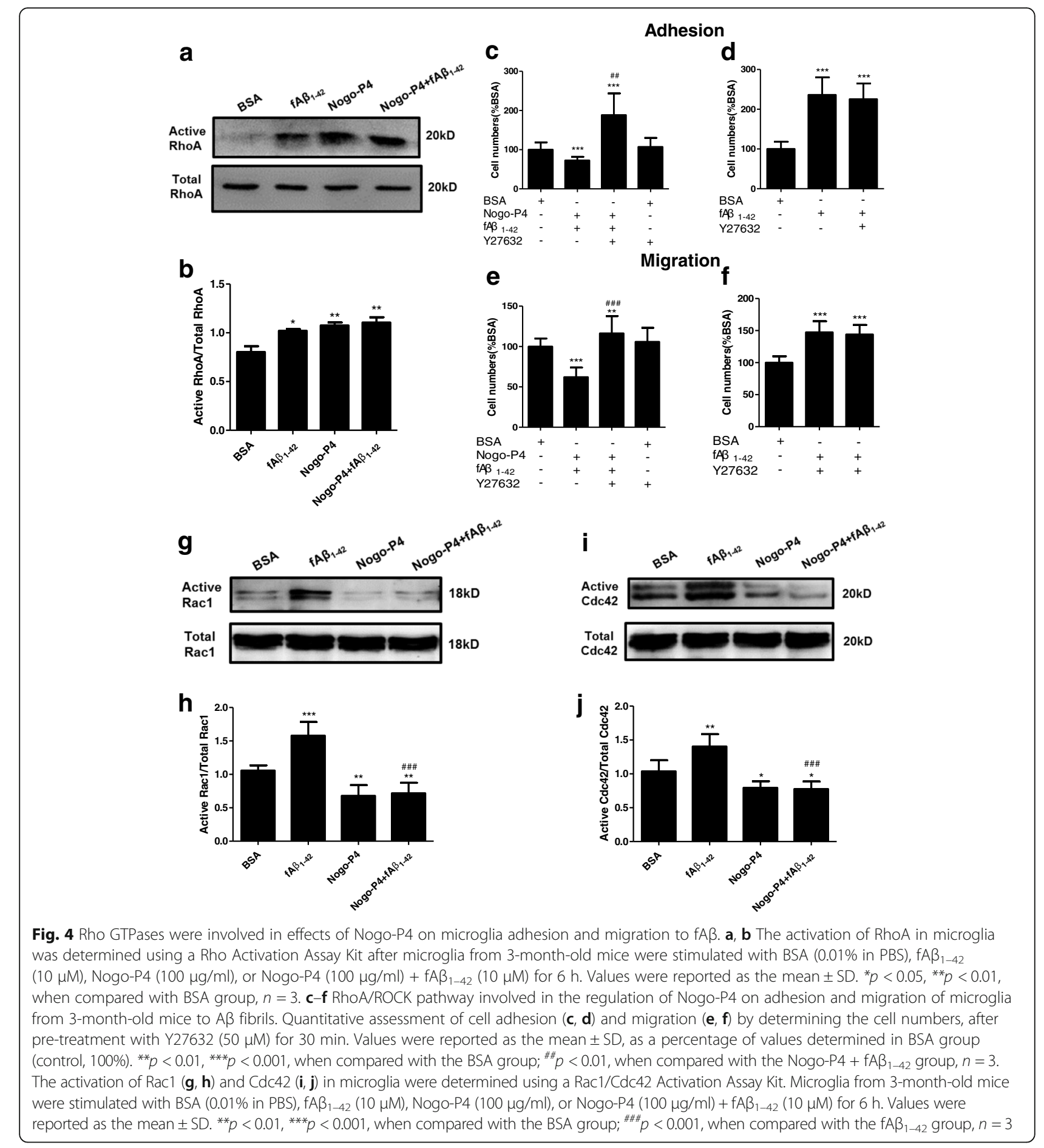

Nogo-P4 on membrane protrusion and the spread areas of adult microglia induced by $\mathrm{fA} \beta_{1-42}$ (Fig. 6c, d). Y27632 pre-treatment could attenuate effects of Nogo-P4 on membrane protrusion and spread areas of adult microglia induced by $\mathrm{fA} \beta_{1-42}$ (Fig. 6f, g). Moreover, NEP1-40 or PI-PLC (Fig. 6c, e) or Y27632 (Fig. 6f, h) treatment alone had no effect on cytoskeleton reorganization of microglia induced by $\mathrm{fA} \beta_{1-42}$. This phenomenon implied that Nogo binding with NgR in adult microglia varied activation of Rho GTPase and downstream molecules such as MLC, cofilin, and IQGAP; further restricted the protrusions extension and cell polarization; and finally resulted in decreased microglial migration and adhesion to $A \beta$ fibrils.

With aging, the increased expression of $\mathrm{NgR}$ in microglia has been reported in our previous study [25]. 

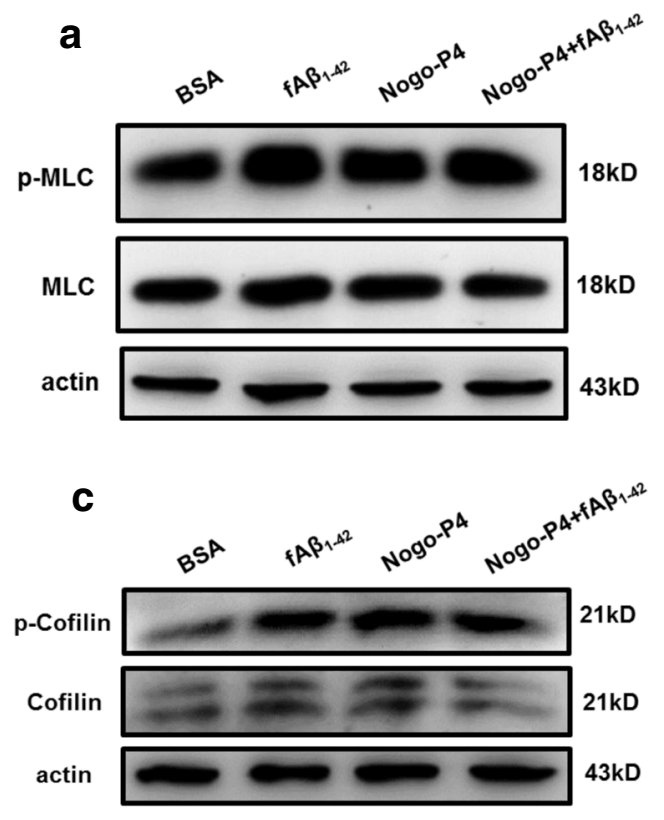

$\mathbf{e}$

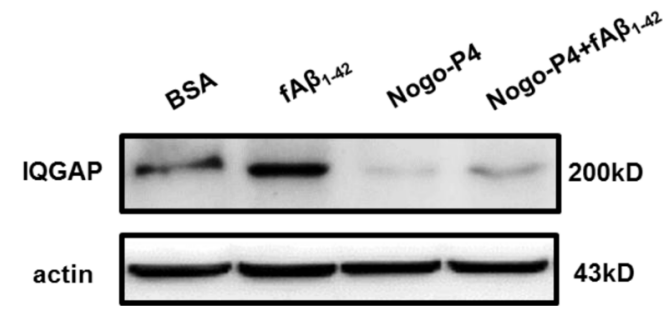

b
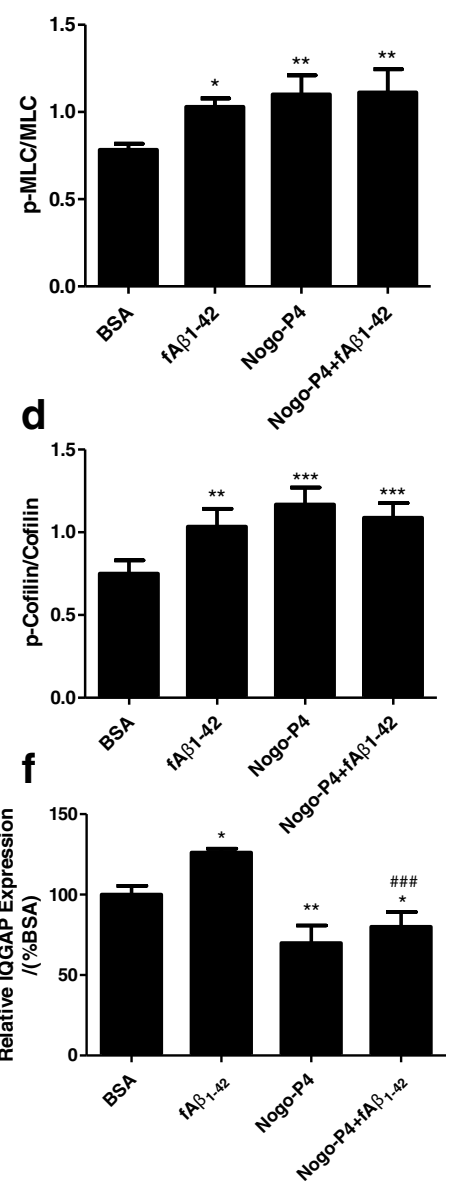

Fig. 5 Effects of Nogo-P4 on phosphorylation of MLC and cofilin and expression of IQGAP in microglia. MLC, cofilin, and IQGAP are key cytoskeleton proteins. After microglia from 3-month-old mice were treated with BSA (0.01\% in PBS), fA $\beta_{1-42}(10 \mu M)$, Nogo-P4 (100 $\left.\mu \mathrm{g} / \mathrm{ml}\right)$, or Nogo-P4 $(100 \mu \mathrm{g} / \mathrm{ml})+f A \beta_{1-42}(10 \mu \mathrm{M})$ for $6 \mathrm{~h}$, phosphorylation of MLC and cofilin, and expression of IQGAP were quantified using Western blot. $\operatorname{MLC}(\mathbf{a}, \mathbf{b})$, cofilin $(\mathbf{c}, \mathbf{d})$. Values were reported as the mean \pm SD. IQGAP $(\mathbf{e}, \mathbf{f})$. Values were reported as the mean \pm SD, as a percentage of values determined in the BSA group (control, 100\%). ${ }^{*} p<0.05,{ }^{* *} p<0.01,{ }^{* * *} p<0.001$, when compared with the BSA group; ${ }^{* \# \#} p<0.001$, when compared with the $f A \beta_{1-42}$ group, $n=3$

The expression of RhoA in microglia during aging was measured by Western blot, and F-actin staining and mean spread area in microglia during aging were examined. The results showed that with aging, expression of RhoA were significantly increased in 3-month-old and 15-month-old microglia (Additional file 3: Figure S3 A, B). There is no difference in expression of 3-month-old and 15-month-old microglia (Additional file 3: Figure S3 A, B). In addition, compared with neonatal and 3-month-old microglia, mean spread area was reduced in 15-month-old microglia (Additional file 3: Figure S3 C, D). Taken together, these results implied that microglia derived from aged mice exhibited increase in the expression of NgR and RhoA and decline in the protrusion extension and cell polarization.
Inhibition of the Nogo/NgR pathway enhanced microglial recruitment toward $A \beta$ deposits and CD36 expression in APP/PS1 mice

To determine the effects of the Nogo/NgR pathway on adhesion and migration of microglia to $\mathrm{fA} \beta$ in vivo, NEP1-40 was intracerebroventricularly administered by continuous infusion into APP/PS1 mice aged from 6 to 8 months old with an Alzet mini-pump. Therefore, recruitment of microglia toward $A \beta$ deposits was determined in APP/PS1 mice. To analyze plaque-associated microglia, confocal analysis of brain sections stained with $6 \mathrm{E} 10$ for $\mathrm{A} \beta$ plaques and Iba- 1 for microglia was determined. As observed (Fig. 7a, b), more Iba- $1^{+}$microglia were recruited to the $A \beta$ plaques in the NEP1-40 group than in the Vehicle group, which was consistent 

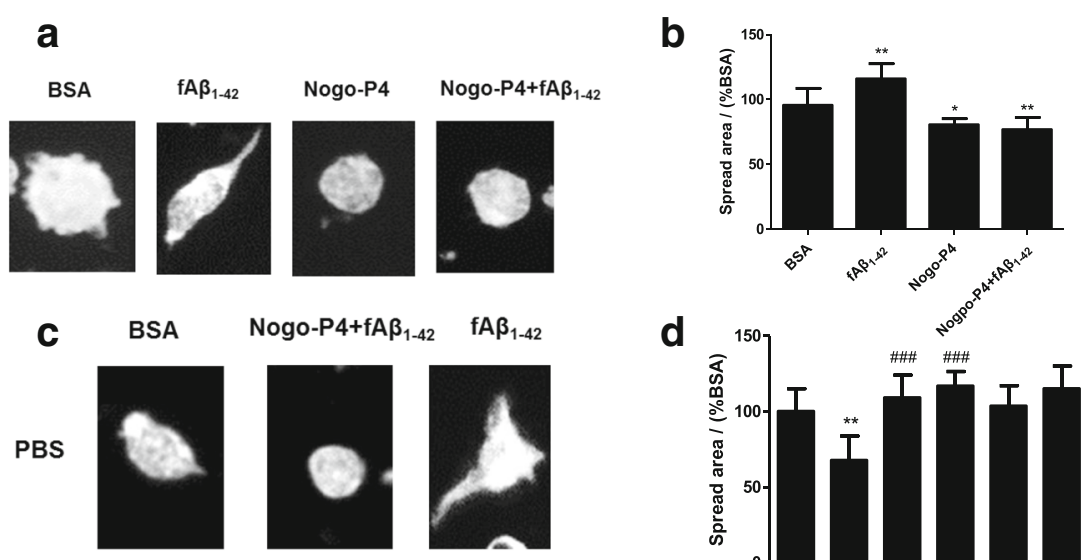

d
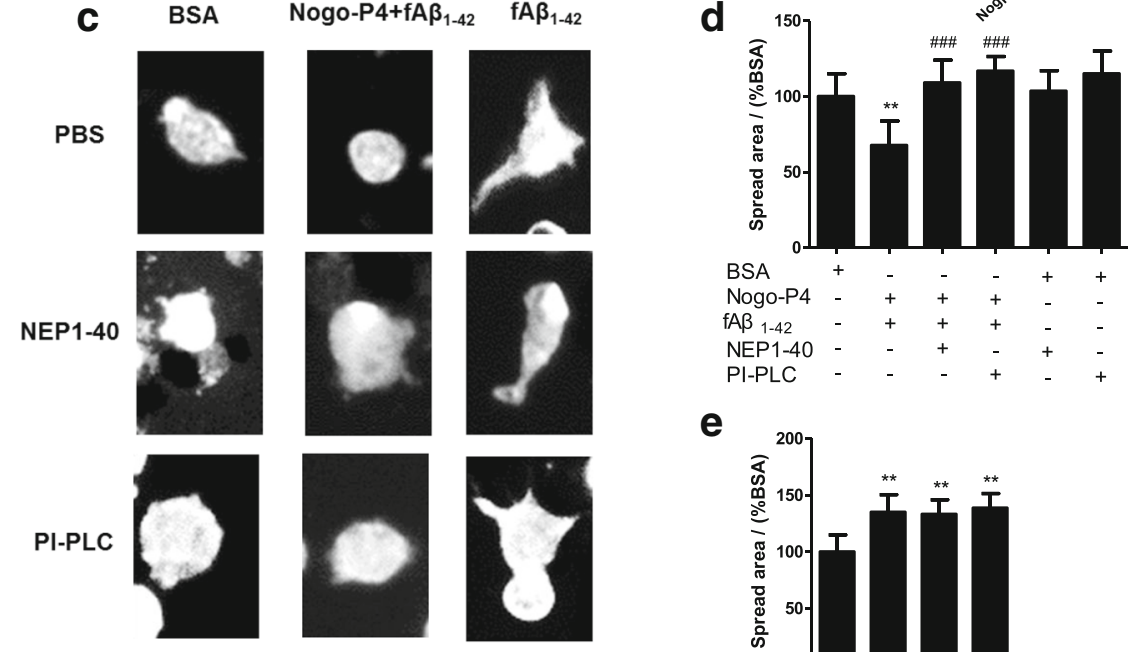

e
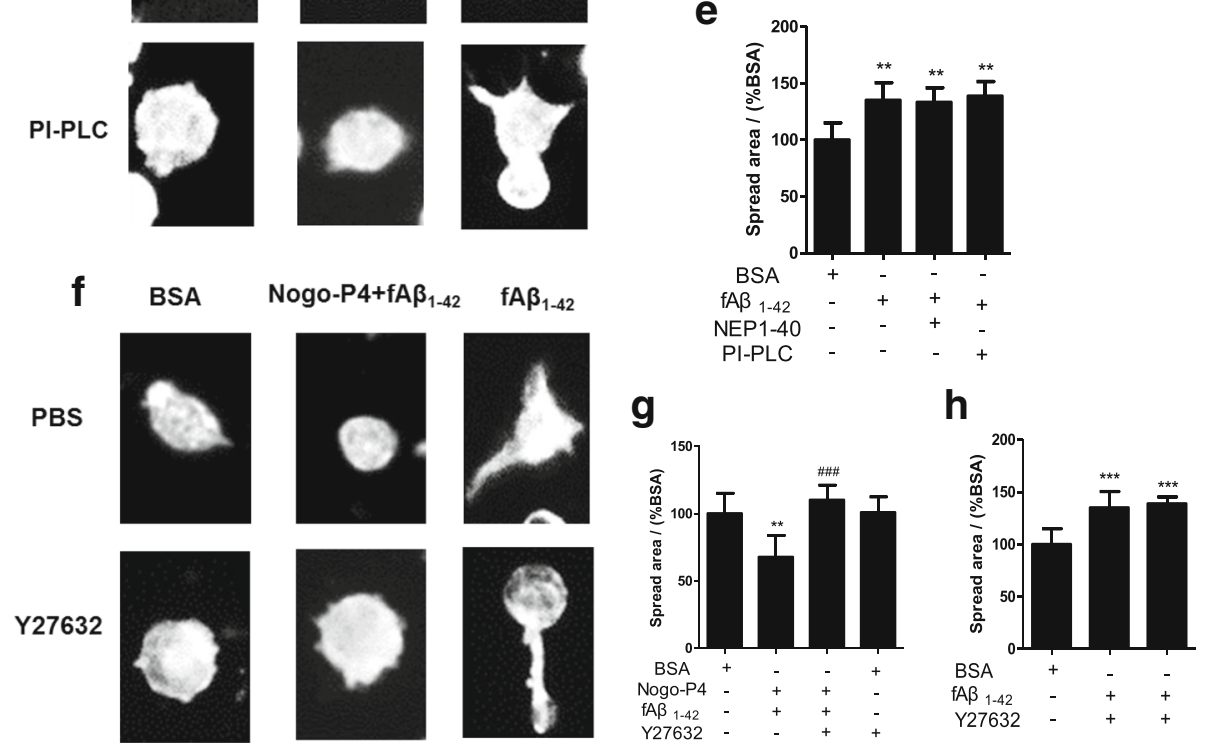

Fig. 6 RhoA/ROCK pathway contributed to regulation of Nogo/NgR pathway on microglia spread and membrane protrusion formation. To explore the effect of Nogo-P4 on cytoskeleton reorganization of microglia and the associated mechanism, F-actin staining and the mean spread area of the microglia were examined. $\mathbf{a}, \mathbf{b}$ Nogo-P4 inhibited microglia spread and membrane protrusion formation induced by A 3 fibrils. Microglia from 3-month-old mice were plated in 96-well plates pre-coated with BSA (0.01\% in PBS), fA $\beta_{1-42}(10 \mu \mathrm{M})$, Nogo-P4 (100 $\left.\mu \mathrm{g} / \mathrm{ml}\right)$, or Nogo-P4 $(100 \mu \mathrm{g} / \mathrm{ml})+f A \beta_{1-42}(10 \mu \mathrm{M})$ for $8 \mathrm{~h}$. a Photomicrographs of microglia stained with rhodamine-conjugated phalloidin. $\mathbf{c}-\mathbf{e}$ The effects of Nogo-P4 on spread and membrane protrusion formation induced by A $\beta$ fibrils were mediated by NgR. Before adding to the wells pre-coated with BSA $\left(0.01 \%\right.$ in PBS), $f A \beta_{1-42}(10 \mu \mathrm{M})$ or Nogo-P4 $(100 \mu \mathrm{g} / \mathrm{ml})+f A \beta_{1-42}(10 \mu \mathrm{M})$, microglia from 3-month-old mice were pre-treated with NEP1-40 $(10 \mu \mathrm{M})$ or PI-PLC $(0.3 \mathrm{U} / \mathrm{ml})$ for 30 min to interrupt the function of NgR. c Photomicrographs of microglia stained with rhodamine-conjugated phalloidin. $\mathbf{d}$, e Quantitative assessment of cell spreading by determining the spread area of the microglia. $\mathbf{f}-\mathbf{h}$ RhoA/ROCK pathway contributed to the regulation of Nogo-P4 on spread and membrane protrusion formation induced by AB fibrils. After pre-treatment with PBS or Y27632 (50 $\mu \mathrm{M})$ for 30 min, microglia from 3-month-old mice were plated in 96-well plates pre-coated with BSA (0.01\% in PBS), fA $\beta_{1-42}(10 \mu \mathrm{M})$, or Nogo-P4 (100 $\left.\mu \mathrm{g} / \mathrm{ml}\right)+$ $f A \beta_{1-42}(10 \mu \mathrm{M})$ for $8 \mathrm{~h}$. f Photomicrographs of microglia stained with rhodamine-conjugated phalloidin. Values were reported as the mean \pm $\mathrm{SD}$, as a percentage of values determined in BSA group (control, $100 \%$ ). ${ }^{*} p<0.05 ;{ }^{* *} p<0.01 ;{ }^{* * *} p<0.01$, when compared with the BSA group, $n=3 .{ }^{\# \#} p<0.001$, when compared with the Nogo-P4 $+f A \beta_{1-42}$ group, $n=3$

with our previous finding in vitro. To confirm these results, the $12 \mathrm{~F} 4$ antibody $[47,48]$ (raised against $\mathrm{A} \beta_{36-43}$, specific for $A \beta 42$ ) was used for $A \beta$ in immunofluorescence. As showed (Additional file 4: Figure S4), more Iba- $1^{+}$microglia were recruited to the $12 \mathrm{~F} 4^{+} \mathrm{A} \beta$ in the NEP1-40 group than in the vehicle group, which was consistent with our previous finding in 6E10 immunofluorescence.

CD36 has been suggested as an important receptor for microglial $\mathrm{A} \beta$ phagocytosis $[49,50]$ and also plays a 


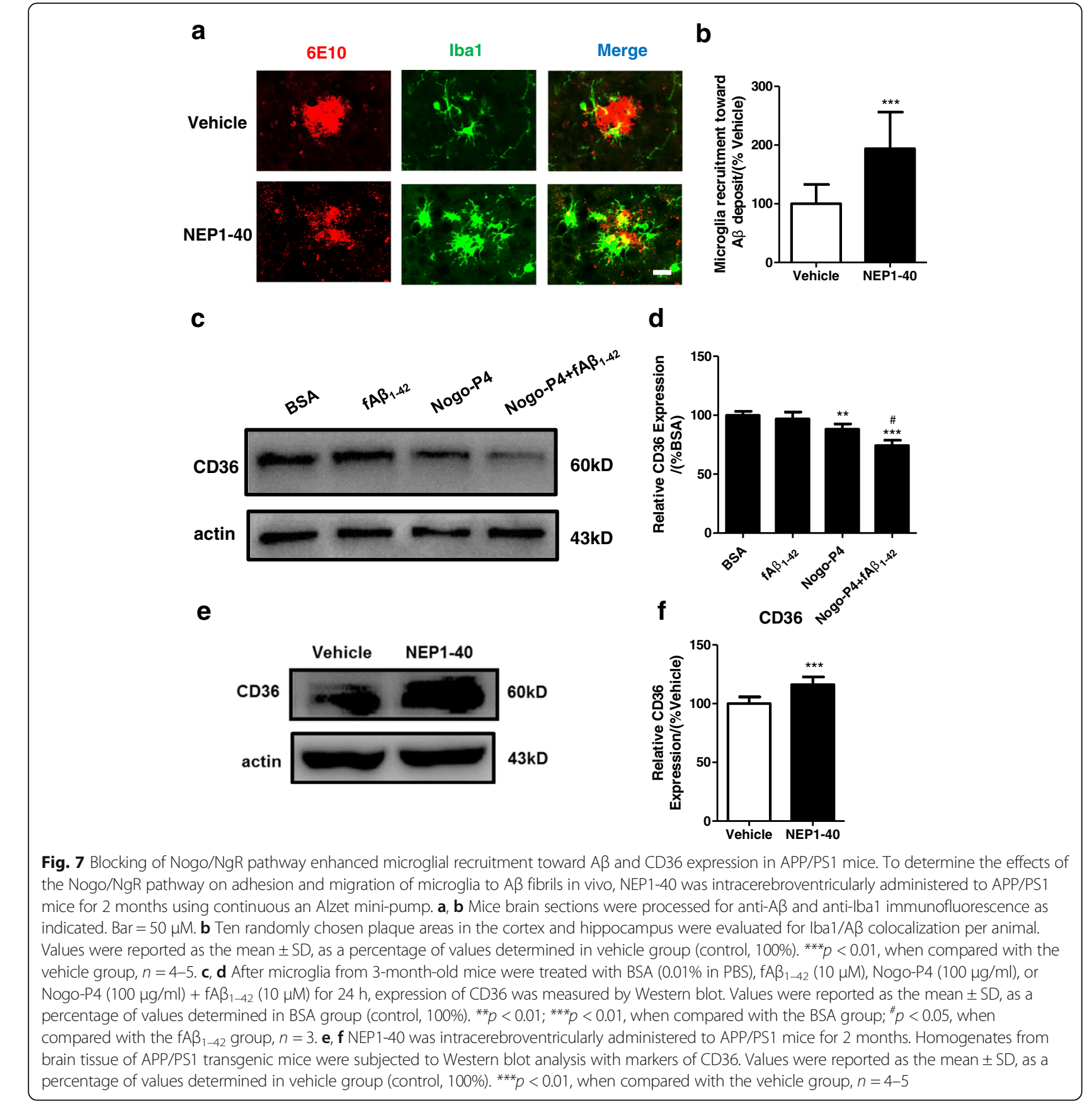

b

pivotal role in the adhesion [51] and migration of microglia to $\mathrm{fA} \beta$ [52]. To measure whether Nogo-P4 affects expression of CD36 in microglia, adult microglia were added into the wells pre-coated with $B S A, f A \beta_{1-42}$, Nogo-P4, or Nogo-P4+fA $\beta_{1-42}$, and cell lysates were collected for Western blot assays. The data showed that Nogo-P4 or Nogo-P4 $+\mathrm{fA} \beta_{1-42}$ significantly attenuated the expression of CD36 in microglia (Fig. 7c, d), indicating that CD36 may involve in the inhibitory effects of Nogo-P4 on adhesion and migration to $A \beta$ fibrils. Corresponding to the experiments in vitro, NEP1-40 increased expression of CD36 in APP/PS1 mice brain (Fig. 7e, f). The results above suggest that the inhibition of the Nogo/NgR pathway promotes microglial recruitment to the $A \beta$ plaques and expression of key phagocytosis receptor and might further increased clearance of amyloid load in APP/PS1 mice.

\section{Discussion}

In this study, we have found that microglia exhibited decreased adhesion and migration to $f A \beta_{1-42}$ by aging. Moreover, the Nogo/NgR pathway inhibited the adhesion 
and migration of microglia to $\mathrm{fA} \beta_{1-42}$ through cytoskeleton reorganization mediated by Rho GTPases (Fig. 8).

From results presented above, three points are particularly noteworthy. Firstly, with aging, the adhesion and migration of microglia to $A \beta$ fibrils were decreased and the Nogo might inhibit adhesion and migration of microglia to $A \beta$ fibrils. Recent studies have indicated that along with aging and the process of disease, the ability of microglia to specifically phagocytose $A \beta$ fibrils is reduced in aged mice $[10,11]$. Because microglial phagocytosis of $A \beta$ is a complex process, in this study, the ability of microglia to adhere and migrate to $A \beta$ was dissected. We found that microglia derived from aging mice exhibited decreased adhesion and migration to $\mathrm{fA} \beta_{1-42}$, which could at least explain reduction in the phagocytosis of $A \beta$ fibrils by microglia with aging. It is known that Nogo-A is localized with $A \beta$ plaques in patients with $\mathrm{AD}$ and APP/PS1 mice, and our previous study indicated that the expression of $\mathrm{NgR}$ is enhanced in microglia with aging [25]. Moreover, binding of $\mathrm{NgR}$ with Nogo-66 inhibits microglial adhesion and migration [22]. Our data showed that Nogo-P4 (the 25-amino acid inhibitory peptide sequence of Nogo-66) could inhibit microglial ability to adhere and migrate fA $\beta$. Moreover, we found that increased in the inhibitory effects of Nogo-P4 on the migration of microglia was exhibited in aged WT and APP/PS1 mice. Furthermore, blocking binding of Nogo-P4 to NgR on microglia by NEP1-40 or PI-PLC pre-treatment rescued the inhibition of
Nogo-P4 on the adhesion and migration of microglia to $\mathrm{fA} \beta$. These data indicate that Nogo/NgR pathway contributed to the effects of $f A \beta_{1-42}$ on the microglial adhesion and migration. Hence, the $\mathrm{Nogo} / \mathrm{NgR}$ pathway might contribute to the age-associated decrease in the ability of microglia to interact with $A \beta$ fibrils.

Secondly, cytoskeleton arrangement mediated by Rho GTPases was responsible for the effects of Nogo on adhesion and migration of microglia to $A \beta$ fibrils. It has been reported that Rho GTPase family, which is downstream of the Nogo/NgR pathway $[22,53]$, can regulate cytoskeleton arrangement during cell migration $[54,55]$. For example, Rho regulates the assembly of contractile, actin, and myosin filaments, while Rac and $\mathrm{Cdc} 42$ regulate polymerization of actin to form peripheral lamellipodial and filopodial protrusions, respectively. Notably, Cdc42 is required for the establishment of cell polarity by affecting the microtubule cytoskeleton and gene transcription [56]. Moreover, Rac1 is required at the front of the cell to regulate actin polymerization and membrane protrusion [57]. Our previous study confirmed that interaction of Nogo-66 and $\mathrm{NgR}$ triggered the activation of RhoA, and the RhoA/ ROCK pathway mediated the effects of Nogo-66 on cell adhesion, migration, and spreading [22] (Additional file 2). In this study, we found that $\mathrm{fA} \beta_{1-42}$, Nogo-P4, or Nogo$\mathrm{P} 4+\mathrm{fA} \beta_{1-42}$ could active RhoA in adult microglia and that the RhoA/ROCK pathway was involved in the inhibitory effects of Nogo-P4 on adhesion and migration of microglia to $\mathrm{fA} \beta$. Furthermore, a recently study found that

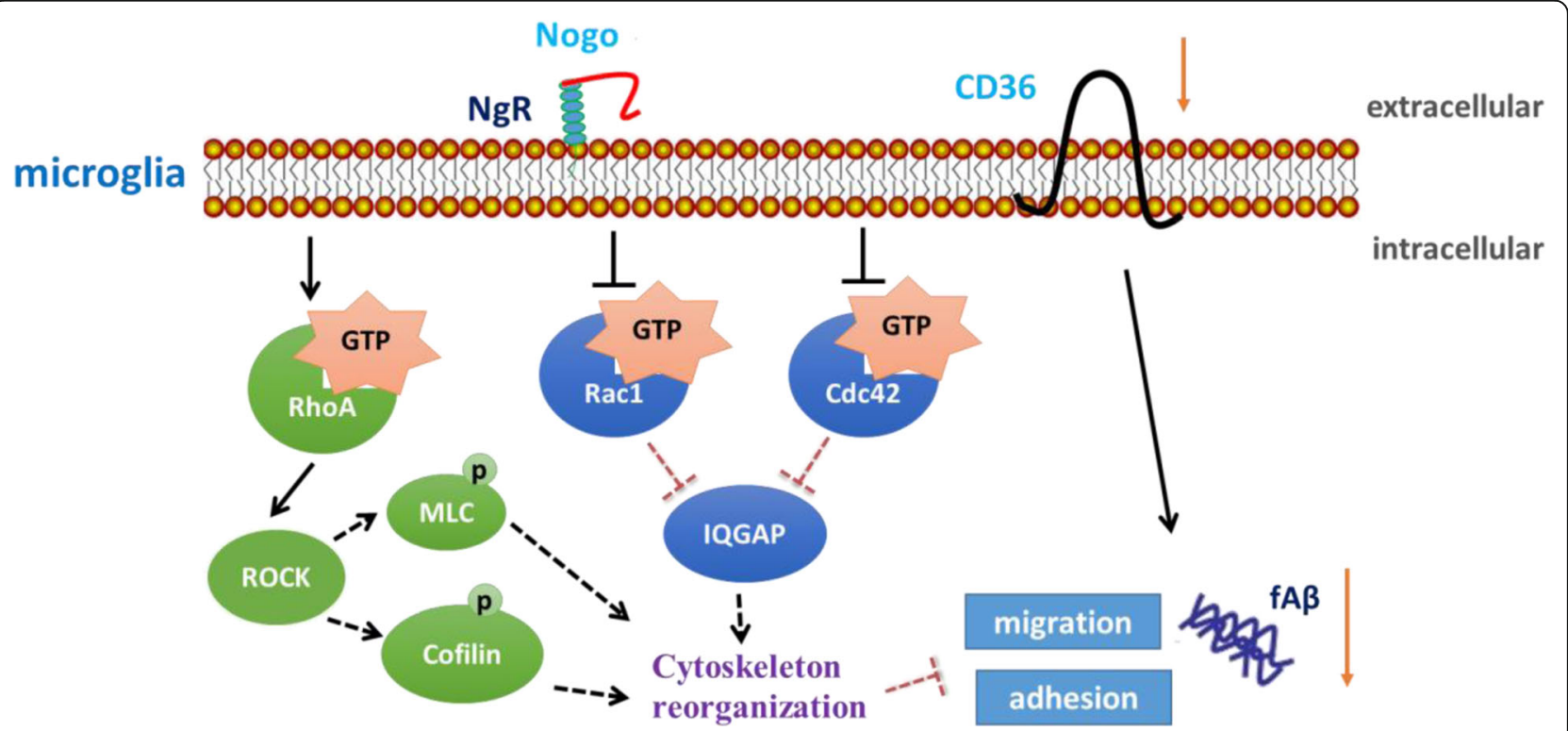

Fig. 8 Schematic diagram of the effects of Nogo/NgR pathway on microglial adhesion and migration to fAß. The interaction of Nogo with NgR enhanced activity of RhoA and phosphorylation of MLC and cofilin and decreased activity of Racl and Cdc42 and expression of IQGAP, which regulated cytoskeleton arrangement. Then, adhesion and migration of microglia to $f A \beta$ was decreased. Moreover, expression of CD36 in microglia was decreased by the Nogo/NgR pathway, which might also contribute to the downregulation of microglial adhesion and migration to fAß 
enhancement in actin polymerization induced by $\mathrm{fA} \beta$ was associated with increased activity of Rac1 and Cdc42 in hippocampal neurons [58]. Nogo-66 also decreased Cdc42 activity in microglia [22]. Our observation also indicated that activity of Rac1 and Cdc42 was induced by $\mathrm{fA} \beta$; meanwhile, the activity was inhibited by Nogo-P4, which further mediated the regulation of the protrusions extension and cell polarization in adult microglia.

Key components of stress fibers include F-actin and myosin; meanwhile, phosphorylated MLC (p-MLC) induces motor activity in myosin. The Rho/ROCK pathway may induce motor activity in myosin by phosphorylating MLC [59], and the Rho/ROCK/MLC/myosin pathway is a crucial determinant for amoeboid motility [60]. Moreover, Nogo-66 signals regulate phosphorylation profile of actin depolymerization factor cofilin, which is involved by RhoA/ROCK pathway [61]. Cofilin could regulate myelin phagocytosis of microglia through its ability to control remodeling of F-actin [62]. Furthermore, IQGAP scaffolding effectors of Cdc42 and Rac [63] may regulate cell polarity and membrane protrusion through actin polymerization, which participates in cell migration [64, 65]. Our results indicated that Nogo-P4 promotes phosphorylation of MLC and cofilin and inhibited expression of IQGAP induced by fA $\beta$ in adult microglia. Moreover, the Nogo/NgR pathway restricted protrusions extension and cell polarization induced by $\mathrm{fA} \beta$ in adult microglia, which was mediated by Rho GTPases.

Thirdly, our observations were proven in APP/PS1 transgenic mice, a common AD animal model. Consistent with our study in vitro, blocking the Nogo/NgR pathway by NEP1-40 significantly induced recruitment of microglia toward $A \beta$ deposits. NEP1-40, a competitive antagonist peptide of Nogo/NgR pathway, has been previously shown to promote axon regeneration and improve outcomes after spinal cord injury and stroke in vivo $[66,67]$. Moreover, our previous study confirmed that the blockage of the Nogo/NgR signal pathway by NEP1-40 in microglia alleviates the formation of $\mathrm{A} \beta$ plaques in APP/PS1 transgenic mice [24]. The observation that recruitment of microglia toward $A \beta$ deposits was increased by NEP1-40 suggests that microglia may phagocytose $A \beta$ easier. CD36 has been suggested as an important receptor for microglial $\mathrm{A} \beta$ phagocytosis [50] and also contributes to the adhesion and migration of microglia to $A \beta[51,52,68]$. Some researchers have demonstrated that RhoA participates in expression of CD36 in macrophages [69] and monocytes [70]. In this study, we found that Nogo-P4 significantly attenuated the expression of CD36 in adult microglia, indicating that CD36 may contribute to inhibition of the Nogo/NgR pathway on adhesion and migration to $\mathrm{AA} \beta$. Moreover, blocking of the Nogo/NgR pathway promoted expression of CD36 which might increase clearance of $\mathrm{A} \beta$ and further ameliorate amyloid load in APP/PS1 mice (Additional file 4).

\section{Conclusion}

In summary, the Nogo/NgR pathway could take part in $\mathrm{A} \beta$ pathology in $\mathrm{AD}$ by modulating microglial adhesion and migration to $A \beta$. Microglia derived from aging mice exhibits decreased adhesion and migration to $f A \beta_{1-42}$. The interaction of Nogo with NgR inhibits adhesion and migration of microglia to $f A \beta_{1-42}$, and Rho GTPases contribute to these effects by regulating cytoskeleton arrangement. Ablation of the Nogo/NgR pathway by NEP1-40 facilitates recruitment of microglia toward $A \beta$ deposits and expression of CD36 in AD mice. These results provide a better understanding of relationship between the Nogo/NgR pathway and interaction of microglia with $A \beta$ and may potentially aid in the development of treatments for $\mathrm{AD}$ progression.

\section{Additional files}

Additional file 1: Figure S1. Congo Red dye binding assay of $f A \beta 1-42$. The aggregation of $f A \beta 1-42$ was validated by the Congo Red dye binding assay. (A) The relative $\mathrm{Cb}$ of $\mathrm{fA} \beta 1-42$. (B) Photomicrographs of $\mathrm{fA \beta 1} 1-42 .{ }^{*} p<0.05 ;{ }^{* *} p<0.01$, when compared with $0 \mu \mathrm{M} \mathrm{fA} 1-42, n=3$. (PDF 120 kb)

Additional file 2: Figure S2. The locally proliferated microglia. (A) The locally proliferated microglia were quantified using IF staining of Ki67. (B) The ratio of Ki67+ cells/total cells (in \%). Values were reported as mean \pm SD (PDF $458 \mathrm{~kb}$ )

Additional file 3: Figure S3. The expression of RhoA and the cytoskeleton in microglia during aging. (A-B) The expression of RhoA in microglia during aging were quantified using Western blot. Values were reported as the mean $\pm S D$, as a percentage of values determined in the neonatal group (control, 100\%). (C, D) To explore the effect of aging on cytoskeleton reorganization of microglia, F-actin staining and mean spread area of the microglia were examined. F Photomicrographs of microglia stained with rhodamine-conjugated phalloidin. Values were reported as mean $\pm S D$, as a percentage of values determined in neonatal group (control, 100\%). ${ }^{*} p<0.05,{ }^{* *} p<0.01,{ }^{* * *} p<0.001$, when compared with neonatal group. (PDF $64 \mathrm{~kb}$ )

Additional file 4: Figure S4. The recruit of $12 F 4+A \beta$ to microglia in APP/PS1 mice. Mice brain sections were processed for anti-12F4 and anti-lba1 immunofluorescence as indicated. Bar $=50 \mu \mathrm{M}$. B: Ten randomly chosen plaque areas in the cortex and hippocampus were evaluated for Iba1/12F4+ $A \beta$ colocalization per animal. Values were reported as the mean $\pm S D$, as a percentage of values determined in vehicle group (control, 100\%). ${ }^{* * *} p<0.01$, when compared with the vehicle group, $n=3-6$. (PDF $71 \mathrm{~kb})$

\section{Abbreviations}

AD: Alzheimer's disease; $A \beta$ : $\beta$-amyloid; fA $\beta$ : Fibrillar A $\beta$; MLC: Myosin-regulatory light chain; NFTs: Neurofibrillary tangles; NgR: Nogo receptor;

PFA: Paraformaldehyde

\section{Funding}

We gratefully acknowledge support from the National Natural Science Foundation of China $(81772063,81572240,81271338)$ and the Specialized Research Fund for the Doctoral Program of Higher Education of China (20130096110011), Natural Science Foundation of Jiang Su Province (BK20151441), and Initial Fund of China Pharmaceutical University (to H.L.). 


\section{Availability of data and materials}

The datasets generated during and/or analyzed during current study are available from the corresponding author on a reasonable request.

\section{Authors' contributions}

In this study, YQF, HL, JNW, CHL, and JW conceived and designed the experiments. YQF, LMY, LY, JNW, HS, and XT carried out experiments. YQF, $\mathrm{CHL}, \mathrm{WJ}$, and $\mathrm{HL}$ analyzed and interpreted the data and wrote the paper. $\mathrm{HL}$ critically reviewed and edited the work. All authors approved the final version of the manuscript.

\section{Ethics approval}

The animal study proposal was approved by the Institutional Animal Care and Use Committee (IACUC) of the Nanjing Medical University Experimental Animal Department with the permit number NJMU/IACUC20131101. All animal tests were carried out in accordance with the US National Institute of Health $(\mathrm{NIH})$ Guide for the Care and Use of Laboratory Animals published by the US National Academy of Sciences (http://oacu.od.nih.gov/regs/ index.htm). This article does not contain any studies with human participants performed by any of the authors.

\section{Consent for publication}

Not applicable. This article does not contain any individual person's data.

\section{Competing interests}

The authors declare that they have no competing interests.

\section{Publisher's Note}

Springer Nature remains neutral with regard to jurisdictional claims in published maps and institutional affiliations.

\section{Author details}

${ }^{1}$ Jiangsu Key laboratory of Drug Screening, China Pharmaceutical University, 24 Tongjiaxiang Street, Nanjing 210009, China. ${ }^{2}$ Department of Pharmacology, Jiangsu Key Laboratory of Neurodegeneration, Nanjing Medical University, Nanjing, Jiangsu, China.

Received: 12 April 2018 Accepted: 5 July 2018

Published online: 20 July 2018

\section{References}

1. Ballard C, Gauthier S, Corbett A, Brayne C, Aarsland D, Jones E. Alzheimer's disease. Lancet. 2011;377:1019-31.

2. Ferretti $M$, Cuello A. Does a pro-inflammatory process precede Alzheimer's disease and mild cognitive impairment? Curr Alzheimer Res. 2011;8:164-74.

3. Mizuno T. The biphasic role of microglia in Alzheimer's disease. Int J Alzheimers Dis. 2012;2012:737846.

4. Li Y, Tan M, Jiang T, Tan L. Microglia in Alzheimer's disease. Biomed Res Int. 2014;2014:437483.

5. Mrak R, Griffin W. Glia and their cytokines in progression of neurodegeneration. Neurobiol Aging. 2005;26:349-54.

6. Sastre M, Walter J, Gentleman SM. Interactions between APP secretases and inflammatory mediators. J Neuroinflammation. 2008;5:25.

7. Yan S, Chen X, Fu J, Chen M, Zhu H, Roher A, Slattery T, Zhao L, Nagashima M, Morser J, et al. RAGE and amyloid-beta peptide neurotoxicity in Alzheimer's disease. Nature. 1996;382:685-91.

8. El Khoury J, Hickman S, Thomas C, Cao L, Silverstein S, Loike J. Scavenger receptor-mediated adhesion of microglia to beta-amyloid fibrils. Nature. 1996:382:716-9

9. Simard AR, Soulet D, Gowing G, Julien JP, Rivest S. Bone marrow-derived microglia play a critical role in restricting senile plaque formation in Alzheimer's disease. Neuron. 2006;49:489-502.

10. Floden A, Combs C. Microglia demonstrate age-dependent interaction with amyloid- $\beta$ fibrils. J Alzheimers Dis. 2011;25:279-93.

11. Hickman SE, Allison EK, El Khoury J. Microglial dysfunction and defective beta-amyloid clearance pathways in aging Alzheimer's disease mice. J Neurosci. 2008;28:8354-60

12. GrandPré T, Nakamura F, Vartanian T, Strittmatter SM. Identification of the Nogo inhibitor of axon regeneration as a reticulon protein. Nature. 2000; 403:439-44.
13. He Z, Koprivica $V$. The Nogo signaling pathway for regeneration block. Annu Rev Neurosci. 2004;27:341-68.

14. Fournier A, GrandPre T, Strittmatter S. Identification of a receptor mediating Nogo-66 inhibition of axonal regeneration. Nature. 2001:409:341-6.

15. Prinjha R, Moore S, Vinson M, Blake S, Morrow R, Christie G, Michalovich D, Simmons D, Walsh F. Inhibitor of neurite outgrowth in humans. Nature. 2000:403:383-4.

16. Gil V, Nicolas O, Mingorance A, Ureña JM, Tang BL, Hirata T, Sáez-Valero J, Ferrer I, Soriano E, del Río JA. Nogo-A expression in the human hippocampus in normal aging and in Alzheimer disease. J Neuropathol Exp Neurol. 2006;65:433-44.

17. Zhu H, Guo H, Hou H, Liu Y, Sheng S, Zhou J. Increased expression of the Nogo receptor in the hippocampus and its relation to the neuropathology in Alzheimer's disease. Hum Pathol. 2007;38:426-34.

18. Vanguilder Starkey HD, Sonntag WE, Freeman WM. Increased hippocampal NgR1 signaling machinery in aged rats with deficits of spatial cognition. Eur J Neurosci. 2013;37:1643-58.

19. Park JH, Gimbel DA, Grandpre T, Lee JK, Kim JE, Li W, Lee DHS, Strittmatter SM. Alzheimer precursor protein interaction with the Nogo-66 receptor reduces amyloid-beta plaque deposition. J Neurosci. 2006;26:1386-95.

20. Masliah E, Xie F, Dayan S, Rockenstein E, Mante M, Adame A, Patrick CM, Chan AF, Zheng B. Genetic deletion of Nogo/Rtn4 ameliorates behavioral and neuropathological outcomes in amyloid precursor protein transgenic mice. Neuroscience. 2010;169:488-94.

21. Park JH, Widi GA, Gimbel DA, Harel NY, Lee DH, Strittmatter SM. Subcutaneous Nogo receptor removes brain amyloid-beta and improves spatial memory in Alzheimer's transgenic mice. J Neurosci. 2006;26:13279-86.

22. Yan J, Zhou X, Guo JJ, Mao L, Wang YJ, Sun J, Sun LX, Zhang LY, Zhou XF, Liao H. Nogo-66 inhibits adhesion and migration of microglia via Gtpase Rho pathway in vitro. J Neurochem. 2012;120:721-31.

23. Fang Y, Yan J, Li C, Zhou X, Yao L, Pang T, Yan M, Zhang L, Mao L, Liao H. The Nogo/Nogo receptor $(\mathrm{NgR})$ signal is involved in euroinflammation through the regulation of microglial inflammatory activation. J Biol Chem. 2015;290:28901-14

24. Fang Y, Yao L, Li C, Wang J, Wang J, Chen S, Zhou X, Liao H. The blockage of the Nogo/NgR signal pathway in microglia alleviates the formation of $A \beta$ plaques and tau phosphorylation in APP/PS1 transgenic mice. J Neuroinflammation. 2016;13(1):56.

25. Liu G, Ni J, Mao L, Yan M, Pang T, Liao H. Expression of Nogo receptor 1 in microglia during development and following traumatic brain injury. Brain Res. 2015;1627:41-51.

26. Moussaud S, Draheim H. A new method to isolate microglia from adult mice and culture them for an extended period of time. J Neurosci Methods. 2010;187:243-53.

27. Nikodemova M, Watters JJ. Efficient isolation of live microglia with preserved phenotypes from adult mouse brain. J Neuroinflammation. 2012;9:73-6.

28. Floden A, Li S, Combs C. Beta-amyloid-stimulated microglia induce neuron death via synergistic stimulation of tumor necrosis factor alpha and NMDA receptors. J Neurosci. 2005:25:2566-75.

29. Sondag CM, Dhawan G, Combs CK. Beta amyloid oligomers and fibrils stimulate differential activation of primary microglia. J Neuroinflammation. 2009;6:328-35.

30. Weinberg RP, Koledova W, Shin H, Park JH, Tan YA, Sinskey AJ Sambanthamurthi R, Rha CK. Oil palm phenolics inhibit the in vitro aggregation of $\beta$-amyloid peptide into oligomeric complexes. Int J Alzheimers Dis. 2018;2018:1-12

31. Chen T, Wang J, Li C, Zhang W, Zhang L, An L, Pang T, Shi X, Liao H. Nafamostat mesilate attenuates neuronal damage in a rat model of transient focal cerebral ischemia through thrombin inhibition. Sci Rep. 2014;4:5531.

32. Dickson D, Farlo J, Davies P, Crystal H, Fuld P, Yen S. Alzheimer's disease. A double-labeling immunohistochemical study of senile plaques. Am J Pathol. 1988;132:86-101.

33. McGeer $\mathrm{P}$, Akiyama $\mathrm{H}$, Itagaki $\mathrm{S}$, McGeer $\mathrm{E}$. Immune system response in Alzheimer's disease. Can J Neurol Sci. 1989;16:516-27.

34. Rozemuller J, Eikelenboom P, Pals S, Stam F. Microglial cells around amyloid plaques in Alzheimer's disease express leucocyte adhesion molecules of the LFA-1 family. Neurosci Lett. 1989;101:288-92.

35. Chen K, Iribarren P, Hu J, Chen J, Gong W, Cho EH, Lockett S, Dunlop NM, Wang JM. Activation of Toll-like receptor 2 on microglia promotes cell uptake of Alzheimer disease-associated amyloid beta peptide. J Biol Chem. 2006:281:3651-9. 
36. Shaffer L, Dority M, Gupta-Bansal R, Frederickson R, Younkin S, Brunden K. Amyloid beta protein (A beta) removal by neuroglial cells in culture. Neurobiol Aging. 1995;16:737-45.

37. Floden A, Combs C. Beta-amyloid stimulates murine postnatal and adult microglia cultures in a unique manner. J Neurosci. 2006;26:4644-8.

38. Becher B, Antel JP. Comparison of phenotypic and functional properties of immediately ex vivo and cultured human adult microglia. Glia. 1996;18:1-10.

39. Slepko N, Levi G. Progressive activation of adult microglial cells in vitro. Glia. 1996;16:241-6

40. Frank MG, Wieseler-Frank JL, Watkins LR, Maier SF. Rapid isolation of highly enriched and quiescent microglia from adult rat hippocampus: immunophenotypic and functional characteristics. J Neurosci Methods. 2006;151:121-30.

41. Grand Pré T, Li S, Stephen MS. Nogo-66 receptor antagonist peptide promotes axonal regeneration. Nature. 2002;417:547-51.

42. Raftopoulou M, Hall A. Cell migration: Rho GTPases lead the way. Dev Biol. 2004;265:23-32.

43. Ishizaki T, Uehata M, Tamechika I, Keel J, Nonomura K, Maekawa M, Narumiya S. Pharmacological properties of Y-27632, a specific inhibitor of rho-associated kinases. Mol Pharmacol. 2000;57:976-83.

44. Fournier A, Takizawa B, Strittmatter S. Rho kinase inhibition enhances axonal regeneration in the injured CNS. J Neurosci. 2003;23:1416-23.

45. Kubo T, Hata K, Yamaguchi A, Yamashita T. Rho-ROCK inhibitors as emerging strategies to promote nerve regeneration. Curr Pharm Des. 2007;13:2493-9.

46. Jin X, Liu Y, Liu J, Lu W, Liang Z, Zhang D, Liu G, Zhu H, Xu N, Liang S. The overexpression of IQGAP1 and $\beta$-catenin is associated with tumor progression in hepatocellular carcinoma in vitro and in vivo. PLoS One. 2015;10:e0133770.

47. Michael H, Akina H, Casey B, Sang-Nam L, Nikolai L, Otzen DE, Eriksen JL, Iris $L$. The neuroendocrine protein 7B2 suppresses the aggregation of neurodegenerative disease-related proteins*. J Biol Chem. 2013;288:1114-24

48. Eimer WA, Vassar R. Neuron loss in the 5XFAD mouse model of Alzheimer's disease correlates with intraneuronal $A \beta 42$ accumulation and Caspase-3 activation. Mol Neurodegener. 2013;8:2.

49. Yamanaka M, Ishikawa T, Griep A, Axt D, Kummer M, Heneka M. PPARy/ RXRa-induced and CD36-mediated microglial amyloid- $\beta$ phagocytosis results in cognitive improvement in amyloid precursor protein/presenilin 1 mice. J Neurosci. 2012;32:17321-31.

50. Lee $\mathrm{C}$, Landreth $\mathrm{G}$. The role of microglia in amyloid clearance from the $A D$ brain. J Neural Transm. 2010;117:949-60.

51. Bamberger ME, Harris ME, McDonald D, Husemann J, Landreth GE. A cell surface receptor complex for fibrillar beta-amyloid mediates microglial activation. J Neurosci. 2003;23:2665-74.

52. Stuart L, Bell S, Stewart C, Silver J, Richard J, Goss J, Tseng A, Zhang A, El Khoury J, Moore K. CD36 signals to the actin cytoskeleton and regulates microglial migration via a p130Cas complex. J Biol Chem. 2007;282:27392-401.

53. Su Z, Cao L, Zhu Y, Liu X, Huang Z, Huang A, He C. Nogo enhances the adhesion of olfactory ensheathing cells and inhibits their migration. J Cell Sci. 2007;120:1877-87.

54. Hall A. Rho GTPases and the actin cytoskeleton. Science. 1998;279:509-14.

55. Aspenström $P$. The Rho GTPases have multiple effects on the actin cytoskeleton. Exp Cell Res. 1999;246:20-5.

56. Etienne-Manneville S, Hall A. Rho GTPases in cell biology. Nature. 2002;420: 629-35.

57. Kraynov V, Chamberlain C, Bokoch G, Schwartz M, Slabaugh S, Hahn K. Localized Rac activation dynamics visualized in living cells. Science. 2000;290:333-7.

58. Mendoza-Naranjo A, Gonzalez-Billault C, Maccioni R. Abeta 1-42 stimulates actin polymerization in hippocampal neurons through Rac1 and Cdc42 Rho GTPases. J Cell Sci. 2007;120:279-88.

59. Gitik M, Reichert F, Rotshenker S. Cytoskeleton plays a dual role of activation and inhibition in myelin and zymosan phagocytosis by microglia. FASEB J. 2010;24:2211-21.

60. Rochelle T, Daubon T, Van Troys M, Harnois T, Waterschoot D, Ampe C, Roy L, Bourmeyster N, Constantin B. p210bcr-abl induces amoeboid motility by recruiting ADF/destrin through RhoA/ROCK1. FASEB J. 2013;27:123-34.

61. Hsieh SH, Ferraro GB, Fournier AE. Myelin-associated inhibitors regulate cofilin phosphorylation and neuronal inhibition through LIM kinase and Slingshot phosphatase. J Neurosci. 2006;26:1006-15.

62. Hadas S, Spira M, Hanisch U, Reichert F, Rotshenker S. Complement receptor-3 negatively regulates the phagocytosis of degenerated myelin through tyrosine kinase Syk and cofilin. J Neuroinflammation. 2012;9:166.
63. Kuroda S, Fukata M, Kobayashi K, Nakafuku M, Nomura N, Iwamatsu A, Kaibuchi K. Identification of IQGAP as a putative target for the small GTPases, Cdc42 and Rac1. J Biol Chem. 1996;271:23363-7.

64. Huang $X$, Jin $Y$, Zhou D, Xu G, Huang J, Shen L. IQGAP1 promotes the phenotypic switch of vascular smooth muscle by myocardin pathway: a potential target for varicose vein. Int J Clin Exp Pathol. 2014;7:6475-85.

65. Gao C, Liang C, Nie Z, Liu Y, Wang J, Zhang D. Alkannin inhibits growth and invasion of glioma cells C6 through IQGAP/mTOR signal pathway. Int J Clin Exp Med. 2015;8:5287-94.

66. Cao Y, Shumsky J, Sabol M, Kushner R, Strittmatter S, Hamers F, Lee D, Rabacchi S, Murray M. Nogo-66 receptor antagonist peptide (NEP1-40) administration promotes functional recovery and axonal growth after lateral funiculus injury in the adult rat. Neurorehabil Neural Repair. 2008;22:262-78.

67. Fang P, Barbay S, Plautz E, Hoover E, Strittmatter S, Nudo R. Combination of NEP 1-40 treatment and motor training enhances behavioral recovery after a focal cortical infarct in rats. Stroke. 2010;41:544-9.

68. Coraci IS, Husemann J, Berman JW, Hulette C, Dufour JH, Campanella GK, Luster AD, Silverstein SC, Khoury JBE. CD36, a class B scavenger receptor, is expressed on microglia in Alzheimer's disease brains and can mediate production of reactive oxygen species in response to beta-amyloid fibrils. Am J Pathol. 2002;160:101-12.

69. Khan OM, Akula MK, Skålen K, Karlsson C, Ståhlman M, Young SG, Borén J, Bergo MO. Targeting GGTase-I activates RHOA, increases macrophage reverse cholesterol transport, and reduces atherosclerosis in mice. Circulation. 2013;127:782-90.

70. Ruiz-Velasco N, Domínguez A, Vega MA. Statins upregulate CD36 expression in human monocytes, an effect strengthened when combined with PPARgamma ligands putative contribution of Rho GTPases in statin-induced CD36 expression. Biochem Pharmacol. 2004;67:303-13.

\section{Ready to submit your research? Choose BMC and benefit from:}

- fast, convenient online submission

- thorough peer review by experienced researchers in your field

- rapid publication on acceptance

- support for research data, including large and complex data types

- gold Open Access which fosters wider collaboration and increased citations

- maximum visibility for your research: over $100 \mathrm{M}$ website views per year

At BMC, research is always in progress.

Learn more biomedcentral.com/submissions 